\title{
Fener Rum Ortodoks Patrikhanesi’nin Ekümenikliği Tartışmaları ve Gerçekler
}

\begin{abstract}
Doç. Dr. Emruhan YALÇIN*
ÖZET

Roma Imparatorluğu'nun 395 yllinda ikiye ayrlması ve Konstantinopolis'in Doğu Roma (Bizans) Imparatorluğu'nun başkenti olmasl nedeniyle, Konstantinopolis Piskoposluğu önem kazanır. Bizans İmparatoru Piskoposluğa Patriklik statüsü ve ekümeniklik unvanı vererek, siyasi olarak gü̧̧ kazanmak ister. Bu durum ekümenik olan diğer kiliseler tarafindan kabul edilmez ve protesto edilir. Osmanll ise, Fener Rum Ortodoks Patriğine bazl yetkiler vererek "milletbassl" olarak görevlendirir. Bu görev sadece Osmanlı sinurları dâhilinde geçerli olup, ekümeniklik anlamına gelmemektedir. Ancak Patrik, özellikle Osmanl İmparatorluğu'nun zayıflama döneminde bu yetkisini kötüye kullanarak, İmparatorluğun parçalanması yönünde çok aktif olarak çalışır. Millî Mücadele döneminde Patrikhane; bir fesat ve ihanet ocağ̆, Rum çeteleri için silah deposu, militan eğitim yuvası rolünü üstlenir. Lozan'la birlikte Patrikhane, Türkiye'deki Ortodoks azınlıkların dinî vecibelerini yerine getiren dinî bir Türk Kurumu haline getirilir. 1980'li yıllara kadar ekümeniklik söz konusu değilken; 1990'll yıllardan itibaren $A B D, A B$ ve Yunanistan'in destekleri ile Patrikhane, ekümeniklik iddialarında bulunmaya bașlar. Ekümeniklik, ne laik Türk Devleti'nin Anayasası ve kanunlart ile ne de Lozan Antlaşması ile bağdaşmaktadır. Patrik, mevcut kanunların kendisine tanımadĭ̆ bir unvanı kullanamaz. Ekümeniklik, sadece Ortodoks dinini ve Ortodoks kiliselerini ilgilendiren bir mesele değildir; aynı zamanda Türkiye Cumhuriyeti Devleti'ni de bağlar. Nüfusunun \% 99'u Müslüman olan Türkiye, kendi topraklarında bağımsız dinî bir Ortodoks otoritesi istememektedir.
\end{abstract}

Anahtar Kelimeler: Patrik, Patrikhane, ekümenik, evrensel, Ortodoks, Rum.

\section{Discussions on the Fener Greek Orthodox Patriarchate Ecumenism and the Facts}

\section{ABSTRACT}

Seperation of Roman Empire in to two and acceptance of Constantinapole as the capital city of Byzantine Empire bring Constantinapole Bishopric into prominence. To gain political power, Byzantine Emperor has given the status of Patriarchy and the title of ecumenism to the Bishopric. This situation has not been accepted by the other ecumenical churches and they have protested him. The 
Ottoman Empire, by giving some competences to the Greek Orthodox Patriarchal, put Patriarch under the duty of "head of people". Although this duty was only valid inside the borders of Ottoman Empire and did not involve any implication to ecumenism, the Patriarch has worked actively, especially during the decline stage, to fragmantate Ottoman Empire's territories. During the period of National Struggle, Patriarchate had the role of mischief and served as focus of betrayal activities, weapon depot for Greek gangs and military training slots. With the Lausanne, the Patriarchate becomes a religious Turkish Institution which deals with the religeiux needs of Orthodox minorities in Turkey. Until the 1980's the ecumenism has not been in the question; since the 1990's the Patriarchate begins to set up a pretension of ecumenism with the support of the U.S.A, E.U. and Greece. Ecumenism does not agree neither with the Constitution and laws of secularistic Republic of Turkey nor the preceptions of Lousanne. The Patriarch can not use a title unless the laws itself allow to. Ecumenism is not just a matter of concern to the Orthodox religion and Orthodox churches; at the same time, it relates with the State of the Turkish Republic. Turkey, which has a population of 99\% of Muslim does not want an independent Orthodox authority in its own territory.

Key Words: Patriach, Ecumenical Patriarchate, Orthodox, Greek Orthodox, universal.

\section{Fener Rum Ortodoks Parikhanesi’nin Ekümeniklik İddiaları}

Yunanca Oikos (ev, barınak), Oikouman (üzerinde insan yaşayan yer) manasına gelmektedir. Dinî bir terim olarak Ekümen, Hristiyanlığın yaşadığı toprakları ve kilisenin "evrensel ", "dünya çapında", "cihanşümul” oluşunu göstermek için kullanılır. Ekümeniklik ise, evrensellik, cihanşümullük anlamlarında kullanılan bir kelimedir. ${ }^{1}$ Ortodoks dünyası açısından, dünyadaki tüm Ortodoksların dinî önderliğini (ruhani liderliğini) ve Ortodoks Kiliseleri arasında birinciliğini ifade eder. ${ }^{2}$ Hristiyanlıktaki "oecumenicus" terimi İslami söylemdeki "medine" (uygar yerleşim birimi) terimi gibi bir anlam da taşır. ${ }^{3}$

Fener Rum Patrikhanesi'nin kuruluşundan itibaren bu güne kadar, tarih içinde inişler ve çıkışlar kaydetmekle beraber, dinî kisve altında siyasi amaçlı faaliyetlerde bulunduğu veya siyasi amaçlar için "Ekümenik Patrik" unvanını kullandığı görülmektedir.

*emruhan2004@gmail.com

Büyük Larousse Sözlük ve Ansiklopedisi, İnterpress Basın ve Yayıncılık A.Ş.,İstanbul,1986, C.VII, s.3591; Elçin Macar, Cumhuriyet Döneminde İstanbul Rum Patrikhanesi, İletişim Yayınları, İstanbul, 2003, 269.

${ }^{2}$ Yorgo Benlisoy-Elçin Macar, Fener Rum Patrikhanesi, Ankara, 1996, s. 153.

3 Muzaffer Özekin, Fener Rum Ortodoks Patrik'i Ekümenik mi?, İrfan Yayımc1lı, İstanbul, 2010, s.11.

${ }^{4}$ Patrik: Yunanca "Patrikhis" kelimesinden gelen, Ortodoksların ve bazı doğu kiliselerinin ruhani liderlerine 
Fener Rum Patrikhanesi'ne ekümenik statüsünün verilmesi, İstanbul'u dünyadaki 270 milyon Ortodoks Hristiyanın dinî merkezi haline getirmek amacına yöneliktir. Ancak Lozan Antlaşmasına göre Fener Rum Patrikhanesi, yalnızca Türkiye'deki Ortodoks azınlığın dinî lideri olarak kabul edilmektedir. Fener Rum Patriğine göre ise, ekümenik sıfatı siyasi bir anlam taşımamakta, sadece tarihî ve dinî bir unvandır.

\section{a. Ekümenikliğin Oluşumu}

M.S. 313 yılından önceki baskılar neticesinde Roma İmparatorluğu'nun dört bir yanına yayılan Hristiyanlık her bölgede farklı farklı yorumlanmış, her cemaat farklı farklı İncillere sahip olmuştur. Sayıları 400'ün üzerinde olan bu İnciller, bir manada 400 civarında farklı teolojik düşüncelere sahip Hristiyan cemaatlerinin ve kiliselerin varlığına işaret etmekteydi. ${ }^{5}$

Hristiyanlığın yayıldığı alanın genişlemesiyle öğretide birliği korumak ve idari bölgeleri tayin etmek amaciyla yedi "Ekümenik Konsil"6 toplanmıştır. Ortodoks Kilisesi ilk yedi Konsili kabul etmiştir. Bu Konsiller şunlardır: 1.Konsil 325, İznik; 2.Konsil 381, İstanbul; 3.Konsil 431, Efes; 4.Konsil 451, Kadıköy; 5.Konsil 553, İstanbul; 6.Konsil 680-81, İstanbul; 7.Konsil 787, İznik. ${ }^{7}$

Katolik ve Ortodoks Kiliseler, Yedinci Konsil'den sonra birbirinden ayrı olarak ve birbirlerinin tanımadığı Konsiller toplarlar. Katolik Kilisesi kendi toplantılarını Konsil olarak adlandırmaya devam eder, Ortodoks Kilisesi ise "Panortodoks" kongreler toplar. ${ }^{8}$ Konsil tarihinde ilk dört genel Konsil Hristiyanlığın iman esaslarının tartışıldığı, hiyerarşik yapının oluşturulduğu toplantılardır.

M.S. 320 yıllarında, İmparatorlukta İsa'nın “Tanrılık vasfı” ile ilgili tartışmalar dinî birliği sarsmaya ve devletin siyasal yapısında da istikrarı bozmaya başlamıştır. Bu nedenle, dinî kontrol altına alabilmek, Hristiyan dinindeki kitap karmaşasını önleyebilmek ve dinî kurumları, siyasal yapı gibi hiyerarşik bir modelde organizasyona tabi tutmak maksadıyla İmparator,

verilen addır. Bir başka tarifle, büyük ve önemli şehirlerin kendi kendini idare etme hakkına sahip kiliselerin

ruhani liderleridir. Bkz. Türkiye Diyanet Vakfi İslâm Ansiklopedisi, XII, İstanbul, 1995, "Patrik" Mad.

${ }^{5} \mathrm{Bu}$ konuda geniş bilgi için bkz. Mehmet Çelik, Resmi Inciller: Kaynakları, Yazarları ve Hristiyan Literatüründeki Yerleri, Erzurum, 1981, s. 19.

${ }^{6}$ Konsil: Kiliselerin temsilcileri olan ruhbanın katıldığı, dinî sorunların konuşulup tartışıldığı ve kararlar alındığı büyük toplantılar (Din bilginleri kurulu toplantısı).

7 Emruhan Yalçın, Atatürk Türkiye'sinde Ekümenik Ortodoks Patrikhanesi ve Bizans Projesi, Siyasal Kitabevi, Ankara, 2008, s.301.

${ }^{8}$ E. Macar, Cumhuriyet Döneminde İstanbul Rum Patrikhanesi, s.30-31. 
M.S. 325 yılında "ilk Ekümenik Konsili" toplamaya karar vermiştir. Konsilde kiliselerin ellerinde farkl1 metinler ihtiva eden İncillerin imha edilmesine ve içlerinden seçilen dört tanesinin "Kanonik" olarak tescil edilmesine karar verilmiştir. Ayrıca bugün tüm Hristiyan dünyasının temel inanç ilkelerini teşkil eden iman esasları ve ekümenik Patrikhanelerin yerleri de önem sırasina göre yine bu Konsilde belirlenmiştir.

İznik Konsili'nin 6. Maddesi gereğince kabul edilen ekümenik Patrikhaneler; Antakya, Roma ve İskenderiye Patrikhaneleridir. Konstantinopolis Kilisesi Ereğli Metropolitliğine bağlı bir Piskoposluk olarak kalmıştır. Bu üç kilise dışında hiçbir kilise ekümenik sıfatına sahip değildir. Bu üç ekümenik kilise kendilerine bağlı bölgelere metropolit atama, azletme... vb. yetkilerle donatılmıştır. Buna göre; Antakya Ekümenik Patrikhanesi, Suriye, Anadolu (İstanbul dâhil) ve tüm Doğu üzerinde; Roma Ekümenik Patrikhanesi, İtalya ve tüm Avrupa üzerinde; İskenderiye Ekümenik Patrikhanesi ise Mısır ve Birleşik Eyaletler (Kuzey - Güney Afrika ve Arabistan) üzerinde yetki ve söz hakkı sahibi olmuştur. Bu tespitte ölçü olarak, bu kiliselerin "Havariler" tarafından kuruluşu yani, "Apostolik kökenli” olmaları kriter olarak göz önüne alınmıştır. İstanbul böyle bir kriterden yoksun olduğu için kendisine böyle bir statü verilememiştir. Bu ilk ekümenik Konsil'in kararları tüm Hristiyan âlemi gibi İstanbul Fener Rum Patrikhanesi tarafından da tartışmasız kabul edilmektedir. ${ }^{10}$ Bu Konsil'in en büyük özelliklerinden biri de, tüm Hristiyan âleminin iman esaslarının teşkil edildiği ilkelerin belirlenmesidir. Hristiyan kiliseleri bütünüyle iman esaslarını I.İznik Konsili'ne dayandırır. ${ }^{11}$

Görüldüğü üzere ilk defa 325 yılında ortaya çıkan ekümeniklik kavramı, bugün hiçbir Hristiyan Kilise ve Mezhebinde tartışılması dahi düşünülmeyen İznik Konsili'nin temel ilkeleri arasında yer almış ve ekümeniklik sıfatını taşıyabilecek merkezler, coğrafî olarak Antakya, Roma ve İskenderiye olarak belirlenmiştir.

Ancak, İmparatorlara göre Apostolik kökenli olmayı kıstas alarak üç ekümenik patriklik tespit edilerek diğer bölgelerin bunlara bağlanmasıyla büyük bir hata yapılmıştı. Siyasal otorite başkentte İmparatorun elinde toplanmışken, dinî otorite başkentten uzak merkezlere verilmişti. Başkentte bulunan en büyük ruhani makam Ereğli (Heracliea) Metropolitliği'ne bağl1

\footnotetext{
${ }^{9}$ Bkz. Documantes of the Christian Church, Selected and Edited by Henry Betterson, 2. Bask1, Oxford Univ. Press, 1963.

${ }^{10}$ Mehmet Çelik, Siyasal Sistem Açısından Bizans Imparatorluğunda Din-Devlet İlişkileri (Kuruluşundan $X$.

Yy.kadar), 2.Bask1, Elazı̆g, 1995, s.15-20.

${ }^{11}$ Münir Yıldırım, Yunanistan ve Ortodoks Kilisesi, Ankara, 2005, s.45.
} 
bir Piskoposluktu. Bu yetki yetersizliği sebebiyle, ülkedeki dinî hareketlere başkent değil, Antakya ve İskenderiye Patrikhaneleri yön veriyordu. Ülkenin yine ilâhiyat tartışmalarının sahnelendiği bir arena durumuna geldiği bir ortamda, İmparator Theodosis, İstanbul Kilisesi'nin mevcut konumunun devlet protokolü açısından yeterli prestije sahip olmadığını görmüş; M.S. 381 yılında İstanbul'da bir Konsil toplamıştır (I. İstanbul Konsili). İmparatorun bu Konsili toplamaktaki esas gayesi dinî kurumları siyasal denetim altına almaktı. Bunun için de başkentteki Piskoposluğun, Ereğli Metropolitliği denetiminden kurtarılıp, Ekümenik Antakya ve İskenderiye Patriklikleriyle eşit düzeye getirilmesi gerekiyordu. İmparatorun verdiği önerge ile İstanbul Piskoposluğu Patriklik statüsüne kavuşturulmuş ve tüm Trakya bölgesi idari yönden kendisine bağlanmıştır.

M.S. 395 yılında Roma'nın ikiye bölünmesi ve Konstantinopolis'in Doğu Roma'nın başkenti olması dolayısıyla Konstantinopolis Patrikliği öne çıkartılmıştır. ${ }^{12}$ İstanbul'a siyasi açıdan Patriklik statüsü verilmesi tüm Hristiyan âleminde rahatsılılı doğurmuştu. Bir yandan da ülkede ilâhiyat tartışmaları olanca hızıyla devam ediyordu. Tüm bu problemlere çözüm bulmak amaciyla, İmparatorun emriyle M.S. 431 yılında Efes'te yeni bir ekümenik Konsil toplanmıştır (Efes Konsili). Kiliseler arasındaki teolojik ihtilaflar görüşüldükten sonra, Patrikliklerin durumu ele alınmıştır. I. İznik Konsili'nin tespit ettiği üç ekümenik Patrikliğin hak ve yetkileri bir kez daha tescil edilmiştir. Böylece, İstanbul'un Piskoposluk olduğu vurgulanmış ve Konstantinapolis Patriği aforoz edilmiştir. ${ }^{13}$

M.S. 450 Yılında Bizans tahtına Marcian geçmiştir. Yeni imparator, üç ekümenik Kilise ile İstanbul Kilisesi arasındaki liderlik çekişmesinden, ülkenin çok büyük zararlara uğradığını ve İskenderiye Patrikhanesi'nin devlete hâkim olmasının İmparatorun siyasal etkinliğini zedelediğini görmüştür. $\mathrm{Bu}$ nedenle, Başkent Kilisesi'ni güçlendirerek ipleri eline geçirmek için M.S. 451 yılında Kadıköy'de bir ekümenik Konsil toplamıştır (Kadıköy (Halidona) Konsili). İmparator, Konsilde istediği neticeyi elde etmek için Konsile bizzat başkanlı etmiş ve Konsil üzerinde tam bir baskı kurarak Efes Konsili kararlarını iptal ettirmiştir. İmparator, üç ekümenik Patrikhanenin statüsünü sarsmak için, Kudüs'ü de Patriklik statüsüne çıkarmıştır. İstanbul Kilisesi'ni güçlendirmek ve İstanbul "Yeni Roma" olduğu için eski Roma'nın imtiyazlarını vermek için tarihte meşhur 28. madde olarak bilinen kanun taslağını Konsile sunmuştur. İmparator'un da bulunduğu bir ortamda Konsile sunulan taslak, Konsil üyelerine zorla kabul ettirilmiştir. Böylece, Başkent Patriği metinde açıç̧a belirtilmese de, zımnen

\footnotetext{
${ }^{12}$ Özdemir İnce, Hürriyet, 12.12.2004.

${ }^{13}$ M. Çelik, Siyasal Sistem Açısından Bizans İmparatorluğunda Din-Devlet İlişkileri, s.27-28.
} 
ekümenik sıfatını almıştır. ${ }^{14}$ Konsile katılan Antakya ve İskenderiye Patrikleri İmparator'un protokol zaruretiyle bu makul isteğini baskı altında imzalamak zorunda kalmışlarsa da, kendi kiliseleri bu kararı reddetmiş ve Patriklerini "ihanetle" suçlamışlardır. ${ }^{15}$ Kendi kiliselerinin baskısıyla bilahare karara karşı çıktıklarını beyan eden Ekümenik Antakya ve İskenderiye Patrikleri görevlerinden alınarak sürgüne gönderilmiştir. $\mathrm{Bu}$ kararı kabul etmediklerinin en büyük delili ise, I. ve II. Efes Konsillerinde İstanbul Patrikhanesi'ni aforoz ederek kiliseden atmalarıdır. Roma delegeleri ilk ekümenik Konsil olan, I. İznik Konsili'nin 6. Maddesini çiğnemek anlamına gelen (kutsal kilise kanunlarına aykırılık), tüm tehditlere rağmen bu siyasi kararı onaylamayarak başkenti terk etmişlerdir. ${ }^{16}$ Sonuçta Asya, Pontus ve Trakya bölgeleri İstanbul'un dinî otoritesi altına girmiştir. Ayrıca, "barbar" diyarlarda piskoposluklar kurma hakkını da elde etmiştir. Bunun anlamı, Patrikhanenin İmparatorluk sınırları dışında da (bağımsız kiliselerin yetki alanına girmemek kaydıyla) yetki alanlarına sahip olmuştur. ${ }^{17}$

Bugün aradan 16 asır geçmesine rağmen, Roma Kilisesi hâlâ, 381 yılında toplanan Mahallî Konsil ve 451 yılında toplanan Kadıköy Konsili'nin kararlarını günümüzde de kabul etmemektedir. Papa Leo, İmparator Marcian'a 22 Mayıs 452 tarihli bir mektup göndererek; “Konsil'de kabul edilen 28. maddenin başta İznik Konsili'nin 6. maddesi ve Konstantinapolis Konsili'nin 3. maddesi ile ters düştügünü; binaenaleyh atalarının kanunlarının, Ruhü'l Kudüs'ün statüsünün ve eski zaman geleneklerinin çiğnendiğini ve Kitab-ı Mukaddes ile ters düşüldü̈̆̈̈nü, bu maddeyi kesinlikle kabul etmeyeceğini" bildirmiştir. ${ }^{18}$

Devletin tasarladığı "Tek devlet, tek kilise ve tek kanun" anlayışı, İmparatorun kilisenin statüsüne müdahalesi, Fener Patrikhanesi'nin ekümenik statü elde etme hırsı İmparatorluğun bütünlügünü tehlikeye atmış ve de Fener Patrikhanesi'nin dünyevi iktidar tutkusu Anadolu, Suriye, Filistin ve Misır'da yüz binlerce Hristiyanın ölümüne ve Hristiyan âleminde kan ve gözyaşına sebep olmuştur. Yani, Fener Patrikhanesi'ne verilen ekümenik statü, kutsal kilise kanunlarına ve kitap-1 mukaddese aykırı olduğu için dinî bir statü olan ekümenikliğin, siyasi bir tasarrufla elde edilmesi, ülkede iki yüzyıl süren dinî isyanların başlamasına ve yüz binlerce insanın katledilmesine sebep olmuştur. ${ }^{19}$

\footnotetext{
${ }^{14}$ Ö. İnce, Hürriyet, 12.12.2004.

${ }^{15}$ M. Çelik, Siyasal Sistem Açısından Bizans İmparatorluğunda Din-Devlet İlişkileri, s.20-25.

${ }^{16}$ M. Çelik, Siyasal Sistem Açısından Bizans İmparatorluğunda Din-Devlet İlişkileri, s.31-33.

${ }^{17}$ Y. Benlisoy-E. Macar, Fener Rum Patrikhanesi, s. 22.

${ }_{18}$ Mehmet Çelik, Türkiye'nin Fener Patrikhanesi Meselesi, Akademi Kitabevi, İzmir, 1998, s.66.

${ }^{19}$ M. Çelik, Türkiye’nin Fener Patrikhanesi Meselesi, s.71-74.
} 
Buna rağmen, V. yüzyılın sonuna doğru Konstantinopolis Patrikliği için Ekümenik Patrik unvanı kullanılmaya başlanmıştır. Ancak bu Roma'nın yerini inkâr etmek anlamına gelmemektedir. Papa tepkisini bir yüzyıl sonra, Patrik III. İonnis, Sen Sinod toplantısının kararlarını "ekümenik" unvanıyla imzalayınca göstermiştir. Bu duruma Roma'nın tepkisi sert olmuşsa da, İstanbul'un aynı zamanda dönemin güçlü imparatorluğu Bizans'ın başkenti olması dolayısıyla etkili olmamıştır. Bunda, Batı Roma İmparatorluğu'nun 476 yılında yıkılmış olmasının etkisi de unutulmamalıdır. ${ }^{20}$ Bu tarihten sonra gelen bütün İstanbul Patrikleri kendilerine "Ekümenik Patrik" unvanını vermişlerdir. Ancak 475 yılinda tahta geçen İmparator Basilikos, İmparatorluğun parçalanmasına ve daha fazla kan dökülmesine engel olmak için 476 yılında Konstantinapolis Konsili'ni toplamıştır. Bu Konsil, aralarında ünlü 28. Kanon da olmak üzere Kadıköy Konsili'nin aldığı bütün kararları gayrı meşru ilân ederek, bu kararları lânetlemiştir. Daha sonra da Fener Patrikhanesi'nin ekümenikliğini de iptal eden kararı perçinlemek için Patrik aforoz edilerek kiliseden uzaklaştırılmıştır. ${ }^{21}$

508 y1linda Konstantinapolis'te toplanan Konsil, Patrikhane'nin ekümeniklik iddialarına bahane olan Kadıköy Konsili'ni bir kez daha lânetlemiştir. İmparator bu sorunu kesin bir çözüme kavuşturmak için, Kadıköy Konsili’nin özgün tutanaklarını getirtmiş̧ir. Üç yıl süren inceleme ve tartışmalardan sonra Kadıköy Konsilinde alınan kararlar yaktııılmıştır. Böylece, Patrikhane'nin ekümenikliğinin sözde kanıtı olan 28. Kanon da yok olmuştur.

Ekümenikliğin şartı olan "apostol” olması yani bir Havari tarafindan kurulmuş bulunması esasından hareketle, Konstantinapolis Kilisesi'nin Aziz Andreas (Andrew) tarafindan kurulduğu ve bu nedenle ekümenik olduğu iddia edilmektedir. Konstantinapolis IV. Yy. başlarında (330) kurulmuş bir şehirdir. Luka'nın yazdığı "Resullerin İş̧leri” adlı eserde; havarilerin uğradıkları veya mektup yazdığı gibi, çevresinden bir havarinin geçtiğine dair en ufak bir imada dahi bulunulmamıştır. Aziz Andreas da, İstanbul'a uğraması şöyle dursun, bu bölgeden geçerek Trakya ve Makedonya yoluyla Roma'ya gittiği hususunda en ufak bir belirti ve işaret bulunmamaktadır. Nitekim Narratio ve B. Dorotheus, Andreas'in Bizans'ta vaaz etmesi, kilise kurmasi; buralardan geçmesinin dahi imkânsız olduğunu kaydetmektedirler. ${ }^{22}$ Roma Kilisesi de böyle düşünüyordu. Papa Leo'nun, dinî yönden itirazları karşısında Patrikhane, önce "Kutsal Havariler Kilisesi" olarak adlandırdığı kilise ile havarilerden bazılarının kutsal emanetlerinin

\footnotetext{
${ }^{20}$ Y. Benlisoy-E. Macar, Fener Rum Patrikhanesi, s. 22-23.

${ }^{21}$ M. Celik, Türkiye'nin Fener Patrikhanesi Meselesi, s.77.

${ }^{22}$ M. Çelik, Türkiye'nin Fener Patrikhanesi Meselesi, s.69.
} 
(haç, asa...) İstanbul'da bulunduğunu ileri sürerek, tezini bunlara dayandırmaya çalışmış ise de; bu da çürük ve zayıf bir dayanaktır. ${ }^{23}$ Bugün de Havarilerin kemiklerinin, kutsal emanetlerinin Papa tarafindan Fener Patrikhanesine getirilerek burada muhafaza edilmeye başlanmasının temelinde yatan faktör, Patrikhane'nin ekümenik olduğunun ispata çalışılması ya da bu işe kendi kendilerini kandırma yöntemidir. Papa da bu yolda kullanılmak suretiyle ekümenikliği kabul etmiş görülmektedir.

Bütün tartışma ve kavgaların sebebi din gibi gözükmesine rağmen, asıl amaç siyaset ve saltanat düşüncesi olduğu için, toplanan Konsillerin hiçbirinde görünen dinî tartışmaların halledilmesi problemleri çözmemiştir. Siyasi güç elde etmek isteyen İmparatorun baskısı ile Konstantinopolis Patrikliği ekümenik yapılmıştır. Anadolu, Suriye ve Mısır'ın İslâm hâkimiyetine girmesiyle, Bizans İmparatorları bu ekümenik statü sevdasından vazgeçmişlerdir. Böylece İstanbul Patrikhanesi artık sadece Bizans'in millî kilisesi olarak kabul edilmiştir. X. yüzyıldan Bizans'ın yıkı1ışına kadar geçen sürede ise, Patrikhane Roma Kilisesi'ne karşı bağımsızlığını koruma telaşına düşmüştür. Esasen en güçlü olduğu dönemde bile iddiasını tutturamamıştır. Sonunda haddini bilmek, gerçeği kabullenmek zorunda kalmış ve VII. Yy.dan itibaren, bu iddiasından vazgeçmiş; asıl konumu olan "Millî Rum Kilisesi" ne dönmüştür. Fakat müzmin bir hastalık haline gelen bu siyasi ve dünyevi iktidar hırsı (özellikle 1050'den itibaren) tekrar tepmiş, bugünlerde de iyice azıtmıştır.

Fatih Sultan Mehmet tarafindan İstanbul'un fethi, Patrikhane için yeni bir dönemin başlangıcı olmuştur. Kendi hâkimiyeti altındaki diğer milletlerin din, örf ve adetlerine dokunmayan ve hatta hoşgörü ile karşılayan Türkler, Rumların sosyal yapısına da dokunmamışlardır. İstanbul'un fethedildiği 29 Mayıs 1453 tarihinde ortada Patrik yoktu. Fatih Sultan Mehmet, cami yaptığı Ayasofya'da kıldığı Cuma namazından çıkışında Patriğin üç gündür kendisini ziyarete gelmediğini sorduğunda; Hristiyan din adamları II. Athanasios'un istifasından beri Patriklerinin olmadığını kendisine söylemişlerdir. Fatih Sultan Mehmet, Patrikliği yeniden dirilten kişi olarak, Doğu ve Batı Kiliselerinin birleşmesine karşı çıkıp köşesine çekilen ve Bizans'ın düşmesinden sonra esir olarak Edirneli bir Türk köylüsüne satılmış olan Sholarios (âlim) lakaplı Yergios Kurtesis'i buldurup İstanbul'a getirmiş ve II. Yenadios (Genedios) adıyla Patrik ilan etmiştir. Fatih Sultan Mehmet, Rum Patriğini Vatikan'ın karşısına bir güç olarak dikmiştir. Ona "ferman", asa ve "Üç Tuğlu Paşa" rütbesi vererek "milletbaşı" (etnark) ilan etmiş, Bizans döneminin de ötesinde yetkilerle donatmıştır. Bu sırada Bizans İmparatoru XI. Konstantin'in kardeşi Prens Thomas'ın kızı Prenses Zoe

\footnotetext{
${ }^{23}$ Mehmet Çelik, Süryani Kilisesi Tarihi, Yaylacık Matbaası, İstanbul, 1987, s.194.
} 
Sophia, Rus Sarayı'na gelin olarak gitmiştir. Böylece 988'de Vladimir'in bir Rum Prensesi ile evlenmesinden sonra asiller arası bir evlenme daha gerçekleşmiş oldu. Bizans'ın Paleolog Hanedanı Rus Çarına sığınınca Ruslar tüm Ortodoks dünyasının ruhani liderliğin dışında Bizans'ın da yasal savunuculuğunu üstlenmiş oldu. ${ }^{24}$

Görüldügü gibi, 1453 senesinde İstanbul fethedildiğinde Bizans Kilisesi ekümenik değil, sadece bağımsız ve millî bir devlet kilisesi olarak beş asırdan beri varlığını sürdürmekteydi. Önceden Bizans tebaası olan insanlar, fetihle birlikte kendilerine din ve vicdan hürriyeti bahşeden Osmanlı Devleti'nin tebaası durumuna gelmişler ve Osmanlı Devleti'nin bir müessesi olan Fener Rum Ortodoks Kilisesi'nde dinî vecibelerini yerine getirmişlerdir. Patrik, Rumların "milletbaşı” olarak Padişaha karşı tüm Rum halkından sorumlu olmuştur. Rum halkı hiçbir dönemde yaşamadığı huzur ve özgürlüğü Türklerin idaresinde bulmuşlardır. Adamantios Polyzodies adında Rum asıllı bir yazar, 1924 yılında Amerika'da Türkiye hakkında çıkmış olan kitabında, bu konuyu çok güzel açıklamıştır; "İstanbul'un zaptından sonra, Rumlar hayli din özgürlüğ̈̈ne kavuştular. Rumlar, bu özgürlüğ̈̈ hem eğitsel, hem yurtsever amaçlar için kullanma açıkgözlülüğ̈̈nü gösterdiler. Her Rum Kilisesi bir gizli okul, her papaz bir ögretmen oldu... Herkesin bildiği bir olay şudur ki, Rum Kilisesi olmasaydl, bir Yunan ihtilali olamazdl. Bu olay bize Rum milletinin neden kiliselerine bu kadar bağll olduğunun nedenini gösterir. Bu kilise salt bir dinî kurul olmaktan fazla bir şeydir; çünkü o, her zaman Yunan ırkının gelenekleriyle, hayalleriyle ve özleyişleriyle bir görülmüştür." 25 Şurası bir gerçektir ki, Osmanlı İmparatorluğu bu hakları verirken dinsel azınlıkların bu hakları millî haklar haline dönüştüreceklerini ve bu yolla İmparatorluğu dağıtacaklarını hiçbir zaman hesap etmemiştir. Aslında Patrikhane makamı Bizans'ın dinî ve dünyevi olan iki yönlü iktidarının ayakta kalan tek taraflı devamı idi. Yani Bizans ölmemiş, Patrikhane'nin şahsında yaşamını devam ettiriyordu. Batılı tarihçiler bu konuda, "Bizans'taki Osmanlı hâkimiyeti Ayasofya'nın duvarlarına sürülmüş badanaya benziyor. Altındaki mozaik Freskler bozulmamıştı" demektedirler. ${ }^{26}$

X. Yüzyıldan Osmanlı İmparatorluğu'nun zayıflama dönemine kadar devam eden beş asırlık süreçte Fener Rum Patrikhanesi'nin ekümenik sıfatı hiçbir zaman gündeme getirilmemiştir. Zaten İstanbul Patrikhanesi'nin ekümeniklik kurduğunu iddia ettiği İskenderiye, Antakya Kiliselerinin üzerinde bulunduğu toprakların, İslam Orduları tarafindan fethedilince, iki

\footnotetext{
${ }^{24}$ M. Özekin, Fener Rum Ortodoks Patrik'i Ekümenik mi?, s.15-16.

${ }^{25}$ Niyazi Berkes, Patrikhane ve Ekümeniklik, Kaynak Yayınları, İstanbul, 2002, s.24.

${ }^{26}$ Adnan Sofuoğlu, Fener Rum Patrikhanesi ve Siyasi Faaliyetleri, Turan Yayıncılık, İstanbul, 1996, s.221.
} 
ekümenik Patrikhane İslam hâkimiyetine girmiştir. Artık İstanbul Patrikhanesi, bu kilseler üzerinde siyasal güç nedeniyle (başkent Patrikhanesiyim) dünyevi hâkimiyet (ekümeniklik) iddiasını kaybetmiş oldu. ${ }^{27}$ Osmanlı'nın zayıflama döneminde ortaya çıkan bağımsız devletlerin bağımsız kiliseleri üzerinde "ekümeniklik" iddialarında bulunmaya başlamıştır. Kendi iddiasına göre neredeyse özerk denilebilecek tarzda imtiyazlar verildiğini ileri sürdüğü devletine muhalif yapılanmalara öncülük etmekten ve bunların içerisinde yer almaktan çekinmemiştir. Bu durumu da genellikle verildiğini iddia ettiği imtiyazların gaspını gerekçe göstererek, meşru bir zemine oturtmaya çalışmıştır. Şimdiye kadar, Fatih Sultan Mehmet tarafindan 1453 yılında Patrikhane'ye verildiği iddia edilen imtiyazlara ait herhangi bir belge bulunamamıştır. İmtiyazların verilmiş olduğunu kabul ederek meseleye yaklaştığımızda dahi Patrikhane, bu imtiyazları veren devlete tâbi bir kurum olduğuna göre, daha sonra aldığı kararlara da uymak mecburiyetindedir.

Değişen şartlar içerisinde "değişerek devam etmek ve devam ederek değişmek" düsturu çerçevesinde, Osmanlı Devleti'nde yapılmaya çalışılan yenileşme hareketlerini, Avrupa Devletleri de desteklemişlerdir. Yapılan yenilikler ve buna bağlı olarak Patrikhanenin "elimden alınıyor" diyerek, dünyayı ayağa kaldırmaya çalıştığı sözde imtiyazları ile ilgili olarak, genelde Gayrimüslimler ve özellikle Ortodokslar, hatta Rumlar memnuniyetlerini belirtmişlerdir. Bu durumdan memnun olmayanlar, sözde imtiyazları sürekli istismar eden başta Patrik olmak üzere Ortodoks din adamlarıdır. Bunlar istismarlarında sadece tâbi oldukları Devletin düşmanları ile işbirliği yapmak ve onu başka devletlere şikâyet etmekle kalmıyor, kendisine tâbi olan cemaate karşı da aynı imtiyazları sömürü aracı olarak kullanıyorlardı. Bundan dolayı Rumlar da dâhil olmak üzere Ortodoks cemaat, devletin uygulamalarını benimseyerek destekliyorlardı. Bazen Ortodoks tebaa, Patrikhanenin baskısıyla, onun istekleri doğrultusunda davranmak zorunda kalıyordu. ${ }^{28}$ Tarihçi Halil İnalc1k; "Fatih Sultan Mehmet tarafindan verilen beratla Patrik'in otoritesi, yalnız Osmanlı ülkesindeki kilise ve manastırlar üzerindeydi. Patrikhane tüm Ortodoks dünyasını temsil eden bir makam değildi." ${ }^{29}$ diyerek, bu Fermanla Patriğe ekümeniklik verilmediğini açık bir şekilde ifade etmiştir. Bağımsız Ortodoks Kiliseleri onun ekümenikliğini kabul etmemekte direndiklerinden dolayı, hiç değilse "eşitler arasında birinci (Pirumus İnter Pare)" unvanını korumaya çalışmaktadır.

\footnotetext{
${ }^{27}$ M. Çelik, Türkiye'nin Fener Patrikhanesi Meselesi, s.93.

${ }^{28}$ Bülent Atalay, Fener Rum Ortodoks Patrikhanesi'nin Siyasi Faaliyetleri (1908-1923), Tarih ve Tabiat Vakfi Yayınları, İstanbul, 2001, s.259.

${ }^{29}$ Sabah, 2 Aralik 2009.
} 


\section{b. Ekümenik Statüsünün Günümüzdeki Durumu}

Ekümeniklik statüsünün günümüzde neden bu denli popüler olmasının sebebi incelenirken, konuyu farklı parametreler eşliğinde gündeme getirmemiz gerektiği ortaya çıkmaktadır. Patrikhane'nin Türkiye aleyhinde çeşitli faaliyetleri ve daha öncesinde Doğu Roma ve Bizans tarafından siyasi güç kanıtı olarak kullanıldığı gerçeğini de göz ard1 etmememiz gerekmektedir. Ekümeniklik statüsünün günümüzdeki durumunu ortaya koymak için Lozan'a kadar ve Lozan'dan sonraki durumunu da kısa olarak incelememizde fayda mütalaa edilmektedir. Buna göre;

\section{(1) Lozan'a Kadar Olan Sürec}

Osmanlı İmparatorluğu'nun yıkılışında, gerek diş devletlerle yaptığı işbirliği ve gerekse yurt içinde çıkardığı isyanlarla Patrikhane, Türk Milleti'nin kalbine saplanan paslı bir hançer gibidir. Patrikhane, Bizans geleneğini yürüterek güttüğü "Megali İdea" ve sonradan da Yunan milliyetçiliğinin tohumlarını, 18. Yy. Osmanlı topraklarına ekmiştir. Kilise, Yunan milliyetçiliğinin asıl temsilcisi olmuştur. Yunan milliyetçiliğine gida veren kaynak ne Eflatun ve Aristo'nun Hellas'1, ne de Batı Avrupa'nın liberal ve sosyalist fikirleridir. Yunan milliyeti en başarılı bir şeklinde papaz teokrasisinin yaratığıdır. Bizde yobazlar ulusal duygulara her zaman yabancı kalmışlardır. Yunanlılarda ise ulusçuluğun rehber ve bekçileri papazlar olmuşlardır. Kiliseyi ve Ortodoksluğu yok farz ediniz, Yunan Ulusu'nun birlik içinde bir ulus olarak ayakta durabileceği şüphelidir. Türk ulusçuluğu, Halife teokrasisini önleyebildiği zaman mümkün olabildi, Yunanlılarda ise bunun tersi olmuştur. Son yüzylllar boyunca Yunan ulusçuluğu Ortodoks teokrasisinin koynunda büyümüş, bir sarsıntıya veya dağılma tehlikesine uğradığı zaman kendini onun kucağına atmıştır. ${ }^{30}$

1908 'de İkinci Meşrutiyet'ten sonra Elefterios Venizelos, Patrikhane'ye yarı resmî bir şekilde, Yunanistan'la birleşme teklifi yapmış; Yunanistan Başbakanlığına geçmeden önce de papaz kıyafeti giyerek Girit'ten İstanbul'a gelerek Patrikhane'ye yeni talimatlar vermiştir. ${ }^{31}$

Mondros Mütarekesi'ni Anadolu'nun paylaşılması için çok önemli bir firsat olarak gören Patrikhane ve ona bağl1 Metropolitler her zamanki gibi şimdi de Yunanistan ile işbirliği içine girmişlerdir. Bu arada Patrikhane bağımsız bir devlet gibi davranmaya başlamıştır. Bu şekilde İstanbul, Anadolu ve Trakya'da ortaya çıkan çete faaliyetlerinde, adalar ve Yunanistan'dan getirilen Rumların Anadolu'ya sokulmalarında, Pontus Cumhuriyeti oluşturulma girişimlerinde ve yine İstanbul'un beynelminel

\footnotetext{
${ }^{30}$ N. Berkes, Patrikhane ve Ekümeniklik, s.23-25.

${ }^{31}$ Uğur Yıldırım, Keşiş Güç, Otopsi Yayınları, İstanbul, 2005, s.73.
} 
hale getirilmesi hedeflerinin gerçekleştirilmesinde Patrikhane ve ona bağlı Metropolitler her şekilde ve her yönde öncülük etmişler yönlendirici olmuşlardır.

Ortodoks Kilisesi ile Yunan ulusçuluğu arasındaki bağın en güzel örneği Kıbrıs'ta görülmüştür. Orada kurulan bağımsız bir cumhuriyetin başına teokratik bir dinin ruhani lideri getirilmiştir. $\mathrm{Bu}$, modern dünyada görülmedik bir garabetti; fakat Yunan ulusçuluğu bakımından tabii bir şeydi. Uluslararası garantili laik bir anayasa, teokratik bir rejimden başka bir şey anlayamayan bir ruhaninin eline, kedinin boynuna ciğer asar gibi teslim edilmiştir. Böylece, kuvvetini anayasadan, halk iradesinden değil milletbaşılık vasfı olan ruhaniliğinden alan kişinin önderliği altında Yunan ulusçuluğu her zaman gördüğümüz rengini Kıbrıs’taki çatışmalara da vermiştir.

Nitekim Lozan Konferansının ilk dönem görüşmelerinin yapıldığı sırada 25 Aralık 1922'de Atatürk, Le Journal Gazetesi muhabiri Paul Herriot'ya Çankaya'da verdiği demeçte bu kurumdan bahsederken; "Bir fesat ve ihanet ocă̆ı olan, ülkede ayrılık ve uyuşmazlık tohumları saçan, Hristiyan vatandaşlarımızın huzur ve refaht için de uğursuzluk ve felâket simgesi olan Rum Patrikhanesi'ni artık topraklarımızda barındırmayı. Bu tehlikeli örgütü ülkemizde tutmamız için ne gibi vesile ve nedenler ileri sürülebilir? Türkiye'nin Rum Patrikhanesi için topraklarında bir slğınak göstermeye ne zorunluluğu vardır? Bu fesat yuvasının gerçek yeri Yunanistan değil midir?...” ifadesinde bulunmuş ve Patrikhane'nin yurt dışına çıkarılmasını istemiştir. ${ }^{32}$

Ancak İngiliz Heyeti Başkanı Lord Curzon başta olmak üzere, Venizelos ve diğer Batılı ülkelerin temsilcilerinin ve ABD'nin baskısıyla Batılı ülkelerin "Patrikhane artık kesinlikle siyasetle uğraşmayacak, sadece Türkiye Cumhuriyeti Devleti'nin vatandaşları olan Rum ahalinin dinî (nikâh, boşanma, vaftiz vb.) vecibelerini yerine getirecek bir kurum olarak kalacaktır" garantisiyle topraklarımızda kalması kabul edilmiştir. Yani Patrikhane, Türkiye'nin içinde İngilizler tarafindan ilerde kullanılmak üzere “Truva'nın Tahta Atı” olarak bırakılmıştır.

Lozan'da müzakereler devam ederken, başta Mustafa Kemal Paşa olmak üzere Türk idarecilerinin kesin kararı, hem azınlık meselesini yurt içinde ve yurt dışında milletlerarası bir statüye kavuşturmak, hem de azınlıklara ait Patrikhane, hahamhane, kilise, havra ve yabancı okullar gibi

\footnotetext{
${ }^{32}$ Atatürk'ün Söylev ve Demeçleri, Cilt III, (1918 - 1937), Atatürk Kültür, Dil ve Tarih Yüksek Kurumu, Atatürk

Araştırma Merkezi, Ankara, 1997, s.57; Hâkimiyeti Millîye Gazetesi, 20 Ocak 1923.
} 
kurumları, hilafet kurumunda yapıldığı gibi kapamaktı. Fakat bunların sadece sözde imtiyazları sinırlandırılabilmiş, kapatılmaları gerçekleştirilememiştir. Neticede Patrikhane; bir antlaşma hükmü ile değil, tasarruf hakk1 Türk Devleti'nde saklı kalmak kaydıyla tek taraflı olarak Türkiye'de kalmasına izin verilmiştir. Patrik ve Patrikhane'nin 1453-1923 yılları arasındaki sahip oldukları bütün siyasi ve idari sözde hak ve imtiyazlarının hepsi kaldırılmıştır. Artık Patrikhane sadece dinî işlerle ilgilenebilecektir. ${ }^{33}$

\section{(2) Lozan'dan Sonraki Durum}

Lozan Antlaşması'nda Patrikhane'nin statüsü açık bir şekilde belirtilmediği gibi, kendisini doğrudan ilgilendiren bir madde de mevcut değildir. Sadece müzakereler sırasında "Patrikhane" adı, sözde eski imtiyazlarının artık son bulduğu ve tamamen Yeni Türk Devleti'ne tâbi bir kurum olduğu hususunda doğrudan ve antlaşma metninde sadece I. Kısmın III. Bölümünde "Ekalliyetlerin Himayesi" başlığı altında yer alan maddelerde ise dolaylı olarak geçmiştir. Böylece Türk Devleti'nin bir kurumu statüsünde, Türkiye topraklarında kalmasına izin verdiği Patrikhanenin, Türkiye'de bulunan diğer Gayrimüslim azınlıklara ait her hangi bir kilise ve sinagogdan farklı bir ayrıcalığı yoktur. Patrik de Türk Vatandaşı herhangi bir Gayrimüslim memurdan farksız, diğer Türk Vatandaşı memurlarla birlikte, Türk Kanunlarına tâbi olup, bütün Türk Vatandaşları gibi aynı hak ve sorumluluklara sahiptir. Başta Patrik olmak üzere, Patrikhanenin bütün görevlileri Lozan'dan sonra, Türkiye'de yaşayan diğer Türk Vatandaşları gibi Türk Anayasası'nın ve Kanunlarının himayesi ve teminatı altına alınmıştır. Lozan Antlaşması ile Patrikhanenin, siyasi ve idari sözde hak ve imtiyazlarının hepsi kaldırıldığı için Patrik, artık sadece dinî yetki ve sorumluluğa sahip olup, Ortodoks Rumların temsilcisi değildir. Buna bağlı olarak, Türk resmi makamları ile cemaat arasında aracılık yapmak gibi bir görevi de kalmamıştır. Artık Patrik, Türkiye'de yaşayan bir ruhani olarak, dinî hüviyetini istismar etmeye teşebbüs etmediği sürece, Türk hoşgörüsüne bağlı olarak sağduyu sahibi bütün din adamları gibi kendisine sayg1 duyulacak ve itibar gösterilecektir. ${ }^{34}$

Böylece Fener Patrikhanesi Lozan'dan sonra, tarihindeki en pasif duruma düşmüştür. 1930'lu yıllara kadar resmî yazışmalarda ve basında, kilisenin başında bulunan dinî lidere "Başpapaz" denilmeye başlanmış, Patrik tabiri dahi kesinlikle kullanılmamıştır. Uzun süreden beri bahse konu olmayan Lozan ve ilgili antlaşma metinleriyle Fatih Kaymakamlığına bağlı

\footnotetext{
${ }^{33}$ Emruhan Yalçın, Atatürk Türkiye'sinde Ekümenik Ortodoks Patrikhanesi ve Bizans Projesi, Siyasal Kitabevi, Ankara, 2008, s.203-211.

${ }^{34}$ B. Atalay, Fener Rum Ortodoks Patrikhanesi'nin Siyasi Faaliyetleri (1908-1923), s.261.
} 
bir dinî kuruluş olarak kabul edilmiştir. Ancak 1986 sonrasında günümüze gelindiğinde Patrikhane ile ilgili konu yeniden kamuoyunu meşgul etmeye başlamıştır.

Patrikhane'nin ekümenikliği tartışması, esas olarak, "Time" dergisi'nin 1963 'teki Patrikhane ve İstanbul'la ilgili kapağı üzerine, Niyazi Berkes'in "Yön" dergisinde bu konuyu ele alan yazılarıyla başlamıştır. ${ }^{35}$ Berkes'e göre; "Ekümeniklik, tarihsel efsaneden başka bir şey değildir, bunun yaratıcısı da Yunan milliyetçiliğidir". İșin aslı; Lozan'dan sonra, Türkiye'nin birçok önemli din-devlet inkılâplarına girişerek, laik devlet yapısına kavuştuğu halde, Patrikhanenin Türk Devleti'nin yeni karakterine uyum sağlayacak reformları yapamaması ve kendini ekümenik bir makam saymak yolundaki "hayali tasavvurlara" kapılmasıdır. Türk-ABD ilişkilerinin yoğunlaştığı ve ABD yardımlarının alındığı bir dönemde, ABD’nin de Patrikhane'nin manevi önceliğinden yararlanarak Sovyetler Birliği'ndeki Ortodokslara etkili olmak istemesi, Patrikhane'nin etkinliğini gündeme getirmiş, bazı faaliyetlerine göz yumulmuştur. ABD böylece, bize Lozan'1 kendi yöneticilerimiz aracılığı ile deldirmiş oldu. Son dönemde ise Patrikhanenin 1980 y1lı sonları ve 1990'lı yıllarda, daha önceki yılların aksine, artık faaliyetlerini açıkça "Ekümenik Patrik" olma yani "Vatikan olma" ve 1971 yılında kapatılmış olan Heybeliada Ruhban Okulu'nu açma, buraya yabancı öğrenci kabul etme, Patrik seçiminde TC Vatandaşı olma zorunluluğunu kaldırma yönünde yoğunlaştırdığı görülmektedir. ${ }^{36}$ Bunda Sovyetler Birliğinde görülen "Glastnos", "Prosterika" ve 1990 yılında da sosyalist hâkimiyetin son bulmasının etkilerini görmek gerekir. Bu dönemde Rusya, Ortodoks dünyasının ABD'nin yönlendirmesine düşmemek ve Moskova Kilisesi'nin tüm Ortodoksluğun temsilcisi ve koruyucusu olduğunu göstermek için çalışmaktadır. ${ }^{37}$ Her ne kadar İstanbul'daki Fener Rum Patrikhanesi, statü itibariyle "eşitler arasındaki birinci" durumundaysa da, son sözün söylenmesinde en büyük pay Rus Ortodoks Kilisesindedir. ${ }^{38}$ Gazi Üniversitesi Öğretim Üyesi Melih Aktaş da bu kapsamda, Amerika'nın Fener Rum Patrikhanesi'ni desteklediğini, Patrikhane'ye "ekümenik" sıfatı kazandırmak için çalıştığını ve bu sayede Doğu Bloku'nun dağılmasından sonra güçlenmeye başlayan Slav Ortodokslarının önünün kesilmesinin amaçlandığını kaydetmiştir. ${ }^{39}$ Bütün bunlara Türkiye'nin AB'ye girebilmek

\footnotetext{
${ }^{35}$ Niyazi Berkes, Yön, 23 Ekim 1964.

${ }^{36}$ Nokta Dergisi, 4-10 Eylül 1994; Aksiyon Dergisi, 1-7 Temmuz 1995; Aytunç Altındal, “Türkiye ve Ortodokslar”, Yeni Türkiye, Mart/Nisan 1995 Özel Sayı, s.460-463; E. Yalçın, Atatürk Türkiye'sinde Ekümenik Ortodoks Patrikhanesi ve Bizans Projesi, s.397.

${ }^{37}$ Hakan Alkan, Tarihsel Süreç İçerisinde Fener Rum Patrikhanesi ve Türkiye, Gazi Üniversitesi Sosyal Bilimler Enstitüsü, Ankara, 1996, s.87.

${ }^{38}$ Aytunç Altındal, "Statü Meselesi Sorunudur”, Nokta, 4-10 Eylül 1994.

${ }^{39}$ Melih Aktaş, "Patrikhane'de Rusya-ABD Savaşı”, Zaman, 21 Eylül 1995.
} 
için sarf ettiği gayretleri ve verdiği tavizleri de göz önünde bulundurmak gerekir. Elefterotipia Gazetesine göre Fener Rum Patrikhanesi, Türkiye'nin AB yolundaki girişimlerinden istifade edebilmek amacıyla, 2004 yılı Aralık ayında, Atina ve Brüksel'e Türkiye'den taleplerini içeren bir mesaj göndermiştir. Patrikhane aynı taleplerini Türk Hükûmeti'ne de göndermiştir. Gazeteye göre bu talepler şöyle sıralanmıştır; ${ }^{40}$

1) Patrikhane'nin Ekümenikliği Türk Hükûmeti tarafından tanınmalı,

2) Heybeliada Ruhban Okulu yeniden açılmalı,

3) Patrikhane'nin hukuki varlığı tanınmalı,

4) Patrikhane ve Rumların mülkleri garantilenmeli,

5) El konulan vakıf statüsü değiştirilmeli,

6) Büyükada yetimhanesi Patrikhane'ye geri verilmeli,

7) Balıklı Rum Hastanesine konulan yüksek vergi kaldırılmalı,

8) Yabancı ülke vatandaşları kilise mensuplarına Türkiye'de oturma ve çalışma izni verilmeli,

9) Patrik seçimi bütün dünyada bulunan despotlar arasından yapılmalı ve Türk vatandaşı olma şartı kaldırılmalı,

10) El konulan kilise ve mülkler geri verilmelidir.

Görüldüğü gibi Patrikhane, karşısına çıkan firsatları ve dönemin gelişmelerini kullanarak $A B$ ve $A B D$ 'nin desteğinden cesaret bulmuş ve genişleme gayretleri içinde olmuştur. Eski Vakıflar Yasası esasları çerçevesinde yeni arazi satın alamayan Patrikhaneye, etrafindaki gayrimenkuller Rum ve Türk işadamları tarafından satın alınıp, bilahare hibe edilmek suretiyle kazandırılmıştır. 2008 yılında yeni çıkarılan Vakıflar yasası ile de Patrikhane'nin yukarıdaki isteklerinin büyük bir kısmı yerine getirilmiştir. ${ }^{41} \mathrm{Bu}$ da Türkiye'nin $\mathrm{AB}$ yolundaki gayretleri neticesinde olmuştur. 1990 yılından sonra, Yunanistan'ın liderliğinde Patriğin Türk Vatandaşı olma şartının kaldırılması kampanyası başlatılmışıı. Bu tarihten sonra da "ekümenik" unvanı kullanılmaya başlanmıştır. ${ }^{42}$ Patriğin bu yöndeki çabalarında; $A B D$ ve AB'nin yanında bazen Rusya'nın da desteğini sağladığı gözlemlenmektedir.

Emekli Büyükelçi Şükrü Elekdağ, ekümenikliğin Türkiye tarafından kabul edilemezliğini ve tehlikesini şöyle vurgulamaktadır: "Burada, ekümenikliğin doğal sonucu olarak, Patriğin sadece Fener Patrikhanesi Sen

\footnotetext{
${ }^{40}$ CNNTURK, 06 Aralık 2004, www.abgs.gov.tr/26.10.2007.

${ }^{41}$ Emruhan Yalçın, Son Haçlı Kalesi: Heybeliada, Elips Kitap, Ankara, 2009, s.138-148.

${ }^{42}$ Mustafa Necati Özfatura, "İstanbul İkinci Vatikan Olma Yolunda", Türkiye, 9 Mayıs 1994.
} 
Sinod'daki Metropolitlerce değil, dünyadaki Ortodoks kiliselerini temsil eden tüm Metropolitler tarafindan seçilmesi gerekeceğini de vurgulayalım. Bu yola gidilmesi, Türk Devleti içinde uluslararası bir dinsel otorite, bir türlü 'dinsel devlet' yaratmak gibi bir sonuç doğurur... Patrikhane'nin gerçek güç tabanı İstanbul'daki 3.000 kişilik Rum Cemaati değil, Amerika'daki ǚ̧ milyonluk Yunan diasporasıdır... Bu söylediklerimiz, Patrikhane'nin 'ekümenik' statü kazanmasının, Türkiye'nin dış ilişkilerinde çok ciddi rahatsızlıklar yaratmanın ötesinde, 'Türkiye'de rejimin dinamitlenmesi' sonucunu doğuracă̆ını ortaya koymaktadır." ${ }^{43}$

İslamcı yaklaşım ise konuya, Hilafet'in de ihya edilmesi gerektiği noktasından bakmaktadır: "Gerek Hilafet, gerekse de Partilik Osmanlı siyasetinde önemli ve belli bir denge oluşturan kurumlardl. Türkiye Cumhuriyeti her ikisinin işlevlerini ellerinden alarak bir anlamda bu dengeyi korumuştur. Eğer bugün Patriklik 'ekümenik bir müessese' olarak ihya edilecekse, o zaman dengeyi korumak için Hilafetin de 'ekümenik bir müessese' yani 'ümmete ait müessese' olarak ihyast gerekir." 44 Patrik Bartholomeos ise uygulamanın farklılığına dikkat çekerek; "Bu tarihî ve sembolik bir unvandir. Bunu rahmetli seleflerim ne Athenagoras ne Dimitrios ne de ben icat ettik. Bu unvan yüzyllardır devam ediyor. Bu unvanın kullanılmasında hiçbir siyasi amaç ya da içerik yoktur. Patrikhane fiilen ekümeniktir. Avustralya'da bir milyon, Amerika'da üç milyon bize direkt bağhl Ortodoks var. Ayrıca Batı Avrupa'da, Girit'te, Onikiadalar'da, Aynaroz'da, Kore'de, Yeni Zelenda'da direkt bize bağll milyonlarca insan olması hasebiyle coğrafi bakımdan ekümeniklik var. Hükümetimiz de bunu gayet iyi bilir ve hiçbir zaman itirazda bulunmamıştır. Oralardaki Başpiskoposlar ve Metropolitleri bizim Patrikhane'nin kutsal Meclisi'nin atadı̆ğıı hükümetimiz çok iyi bilir. Örneğin geçen yıl Amerika Başpiskoposluğu'nu seçtik. Ekümenik Patriklik Ortodoksluğun bir iç konusudur. Hükümetimiz Ortodoksluğun işlerine karlşma eylemi gösterirse bu laikliğe aykırıdır... Bu unvanı, statümüzün bu içeriğini ilk yüzyıllarda toplanmış olan ekümenik Konsillerden alyyoruz. Bunu ben de haleflerim de değiştiremeyiz. Kimse değiştiremez. Ekümenik Konsillerin kuralları bizim için kutsaldır, bağlayıcıdır." ${ }^{45}$ diyerek, bu unvanı kullanması gerektiğini ve hatta kullandığını ifade etmiştir.

ABD artık iki başlı bir dünya istememektedir. Bu nedenle Rusya'nın yeniden yapılanmasının temelini teşkil eden iki ayaktan biri olan Rus Ortodoks Kilisesinin denetimini eline geçirmek istemektedir. Bu projenin

\footnotetext{
${ }^{43}$ Şükrü Elekdağ, "Patrikhane’nin Statüsü”, Milliyet, 3 Aralık 1995.

44 Altay Ünaltay, "Ekümenik Patrik ve Tarihimizin Diğer 'Ekümenik' Kurumları”, Yeni Safak, 12 Kasım 1995.

${ }^{45}$ Cumhuriyet, 20 Temmuz 1997.
} 
tahakkuku için önünde üç engel bulunmaktadır: Türkiye, Vatikan ve Katolik âlemi, Ortodoks âlemi ve Rusya. Yenidünya projesinde Ortodoks Âleminin Fener Patrikhanesi'nin şemsiyesi altında yeniden yapılanması çok ince, dinî ve politik hesaplara dayanmaktadır. $\mathrm{Bu}$ projenin hazırlık safhaları şunlardır: ${ }^{46}$

-Fener Patrikhanesi'nin Lozan Antlaşmasını delme faaliyetleri: Patrikhane'nin hareket alanının önündeki en büyük engel Lozan'ın ilgili maddeleri ve buna dayanılarak hazırlanan Türkiye Cumhuriyeti'nin kanun maddeleridir.

-Fener Patrikhanesi'ne Vatikan statüsü kazandırma projesinin hazırlık safhasının ikinci basamağı, Türkiye ve Ortodoks Dünyasının kamuoyunu buna hazırlamak teşkil etmektedir. Bu amaçla, dünya kamuoyunun dikkatini konuya çekmek için, günümüz insanının en duyarlı olduğu konular tespit edilerek (din, bilim, çevre), Fener Patrikhanesi'nin önderliğinde sempozyumlar düzenlemek, bu sempozyumlara çeşitli ülkelerden din, bilim, sanat, siyaset ve iş dünyasından uluslararası şöhrete sahip kişilerin katılımını sağlayarak, basın yoluyla dünya kamuoyunun ilgisini Fener Patriği üzerine yoğunlaştırmak, bu faaliyetlerin her safhasında Fener Patrikhanesi'ni öne çıkarmak ve bunu dünya kamuoyunun şuuraltına yerleştirmek hedeflenmektedir. Bu amaçla, Dünya Barışına Katkı Toplantısı (İstanbul1994), Vahiy ve Çevre Sempozyumu (Petnas adas1-1995), Din-Bilim ve Çevre Sempozyumu (Trabzon-Selanik- 1997) düzenlenmiştir. Patrik Bartholomos, Avrupa Komisyonu Başkanı Jacques Santer'in himayesinde, 20-28 Eylül 1997 tarihlerinde "Karadeniz'deki Çevre Sorunları" adıyla, Karadeniz'e açılarak, bazı işadamları ve Çevre Bakanlığı'nın finanse ettiği bir gemide düzenlenen Sempozyumda gerçek niyetini ortaya koymuştur. Yunanistan'dan bazı siyasilerin de içinde bulunduğu gemi Karadeniz'de büyük limanlara uğrayarak çevre kirliliğine dikkat çekerken, faaliyet Patrikhane'nin Ekümenikliğinin gövde gösterisi olarak yorumlanmıştır. Trabzon'da Ülkücü Örgütlerin düzenledikleri bir protesto ile heyetin gemiden inmelerine mani olunmuştur. Başka bir Sempozyum 1999'da "Tuna Nehri'nin Kirliliğine Yol Açan Sorunlar" başlığıyla yine Karadeniz'de olmuştur. $^{47}$

-Fener Patrikhanesi'ne verilecek ekümeniklik statüsünün Türkiye'ye getireceği faydaların(!), yerli ve yabancı basında işlenerek Türk kamuoyunun konuya sıcak bakmalarını sağlamak. Bugün için bu hedeflerine ulaşmış gibi görünmektedirler. Çünkü aydın diyebileceğimiz birçok köşe

\footnotetext{
${ }^{46}$ M. Çelik, Türkiye'nin Fener Patrikhanesi Meselesi, s.14-30.

${ }^{47}$ Yunanistan (Türkiye'deki Yunan Büyükelçiliği tarafından yayımlanan bülten), Sayı:13, Haziran 2002.
} 
yazarı ve akademisyenlerimiz, hatta siyasi liderlerimiz Patrikhane gibi düşünmektedirler.

—İstanbul'un "Mega Köy” bahanesiyle bölünerek sur içinin yeniden düzenlenmesi ve bir dünya metropol kültür merkezi olarak Konstantinapolis'in yeniden ihyası projesi. Fener Patrikhanesi için düşünülen nihaî hedef "Vatikan Modeli" olduğuna göre, bir toprak parçasına da ihtiyaç olacaktır. Bu da, Patrikhane'nin tarihi misyonuna uygun olan yerde, hiç şüphesiz surlar içindeki İstanbul'dur. İstanbul'la ilgili en korkunç proje 1995 yılı sonunda ortaya atılmıştır. ABD'li uzmanlarca hazırlanan proje devrin Başbakanı Tansu Çiller tarafından basına açıklanmıştır. Projeye göre İstanbul üçe bölünecekti;

1. Anadolu Yakası: tamamen yerleşim birimi olacak,

2. Surlar içindeki İstanbul; tarihî ve kültürel İstanbul olacak,

3. Surlar dışındaki İstanbul: sanayi, yerleşim ve iş merkezlerinden oluşacaktı. Böylece Türkiye'nin federasyona dönüştürüleceği planda İstanbul'un yeniden başkent olma, sonra da ayrı bir devlet olma yolu açılmış olacak idi.

-Heybeliada Ruhban Okulu'nun yeniden açılması faaliyetleri: Heybeliada Ruhban Okulu 1971 yılında "özel üniversiteleri" kapatan kanunun yürürlüğe girmesiyle kapanmışt1. Kısa bir süre sonra "özel üniversitelerin" devlet denetiminde olma şartı ile açılmasına izin verildi. Ancak Patrikhane bu şartı kabule yanaşmadığı için, Heybeliada'daki okul açılmamıştır. ${ }^{48}$ Heybeliada Ruhban Okulu'nun yeniden açılması, Patrikane'nin ekümenikliğinin önünü aralayan en önemli faktördür.

-Fener Patriğinin Cezaropapizm ${ }^{49}$ faaliyetleri: Katolik Kilisesi, Reform ve Rönesans hareketleri ile dünya hâkimiyeti düşüncesinden vazgeçmiş, Vatikan'da sembolik bir devlet anlayışı ile iktifa etmiştir. Fakat İstanbul'daki Patrikhane, bu anlayışı hiçbir zaman terk etmemiştir. Siyasal iktidarın güçlü olduğu dönemlerde imparator hem dünyevi hem ilahî gücü Tanrı adına temsil etmiştir. Siyasi iktidarın güçsüz olduğu dönemlerde ise bu iki gücü Patrikhane temsil etmeye çalışmıştır.

Patrikhane'nin bütün bu girişimlerinin Türk basınında yer alması ve eleştirilmesi üzerine, kamuoyunu yatıştırmak gayesiyle, Patrikhane sözcüsü Prof. Dr. Gnadios Limovris 13 Haziran 1994 günü bir açıklama yaparak,

\footnotetext{
${ }^{48}$ Emruhan Yalçın, Son Haçlı Kalesi: Heybeliada, Elips Kitap, Ankara, 2009, s.78-81.

${ }^{49}$ Cezaropapizm: Patrikhane'nin Bizantinist bir anlayışla egemen güç olma arzusu, Bizans İmparatorluğu'nu temsil ettiğine dair inanışı. M. Çelik, Siyasal Sistem Açısından Bizans Imparatorluğunda Din-Devlet İlişkileri, s.61 vd.
} 
"Ortodoksların başkenti olmak ve Türkiye içinde ayr bir devlet gibi davranmak niyetinde olmadıklarını" açılamak gereğini duymuştur. ${ }^{50}$

ABD’nin "Yeni Dünya Düzeni Projesi" Rusya ve Ortodoks Âlemi kadar ve hatta onlardan daha fazla, Türkiye'yi ilgilendirmektedir. Şayet konuya gereken hassasiyet gösterilmezse bunun faturası İstanbul ve Trakya Bölgesinin Türkiye sınırları dışına çıkarılması demektir.

O halde Türkiye ne yapmalıdır?

Birinci aşamada: Diyanet İşleri Başkanlığına bağlı, Patrikhane ile direkt irtibatta bulunacak, Patrikhane'nin faaliyetlerini takip edecek uzman ve sürekli bir Şube kurulmalıdır,

İkinci aşamada: Fener Rum Patrikhanesi'nin Türkiye Cumhuriyeti'nin bir kurumu olduğu ve Türkiye Cumhuriyeti Kanunlarına uyması gerektiği sık sık hatırlatılarak, kanun ihlâllerini önlemek, yapacakları her faaliyette Diyanet İşleri Başkanlığı'nın ilgili Şubesinden bir personelin katılmasını sağlamak ki bu her aşamada sürekli uygulanacak bir faaliyet olacaktır.

Üçüncü aşama: Patrikhane konusunda $\mathrm{ABD}$ ile görüş teatisinde bulunulmalı, Türkiye'nin kabul etmediği projeler üzerindeki çalışmaların yapılmaması hususunda baskı yapılmalıdır,

Dördüncü aşamada: Patrikhane konusundaki Türk tezlerini Rusya ile paylaşmak ve müşterek hareket etmek gerekmektedir.

Çok büyük bir dikkatle hazırlanmış olan bu plân çerçevesinde, çeşitli aşamalardan geçilerek nihaî hedefe varılacaktır. Türkiye'nin, Lozan Konferansı'nda Patriğin siyasi faaliyetlerinden şikâyetçi olmuşken, şimdi Patrikten siyasi yardım istemesi, geçmişteki tecrübeleriyle tutarlı değildir. Türkiye-Yunanistan ilişkileri ya da $\mathrm{AB}$ gibi konularda Patrikhaneyi kullanmak, onu siyasetin içine çekmek anlamına gelir ki, bu da Patrikhane'nin ekümenikliği yolunda almak istediği en önemli bir mesafedir.

\section{Hedefi}

c. Ekümenik Olarak Yürütülen Faaliyetler ve Patrikhane'nin Nihâi

Günümüzde ekümeniklik gölgesine sığınarak Fener Rum Patrikhanesi'nin ulaşmak istediği hedefler şunlardır; ${ }^{51}$

Birinci aşamada; ekümeniklik statüsü ile Patrikhane ve bağlı ruhanilerini Türkiye Cumhuriyeti Kanunlarının vesayetinden kurtarmak. Türkiye bunu tanıdığı anda artık Patrikhane'yi kontrol edemeyecektir.

${ }^{50}$ Günaydın, 13 Haziran 1994.

${ }^{51}$ M. Çelik, Türkiye'nin Fener Patrikhanesi Meselesi, s.31-40. 
İkinci aşamada; Sur içi İstanbul'u, Patrikhane'nin ekümenik damgası altında eski Kostantinapolis olarak yeniden ihya etmek. Sur içi İstanbul esas şehirden ayrılır, Kültürel ve din çehresi öne çıkarılırsa, Vatikan'a giden yolda çok büyük bir merhale kat edilmiş olacaktır. Zira BM, AB, UNESCO ve Dünya Kiliseler Birliği gibi kuruluşların parasal yardımıyla şehrin eski Bizans ve Hristiyan çehresi ön plâna çıkarılmaya çalışılacaktır.

Üçüncü aşamada; Hristiyan Ülkelerin İstanbul'da dinî ataşelikler açmalarını sağlamak. Özellikle Hristiyan ülkeler böyle fırsatı adım adım takip ediyorlar.

Dördüncü aşamada; $\mathrm{BM}, \mathrm{AB}$ ve UNESCO gibi uluslararası kuruluşların desteğiyle, surlar içindeki tarihî Konstantinopolis'in "açık şehir" haline getirilerek Türkiye'nin hükümranlık hakkını tartışmaya açmalarını sağlamak. Birçok uluslararası kuruluş tarihî Konstantinapol'de restorasyonlarda katkı sahibi olmak isteyeceklerdir. Şehrin Bizantinist ve Hristiyan karakteri ön plâna çıkarılacak, şehir dünyaya açık bir ortak metropol haline gelecek, dinî ataşelikleriyle, kültür mozaiğiyle artık bir Türk şehri değil, şimdilik sembolik de olsa 270 milyonluk Ortodoks dünyasının kalbi ve kıblesi olacaktır. Bugün gelinen noktada ise, Unesco'nun tarihi yarımadayı koruma altına alması ve restorasyon çalışmalarının başlaması da bunun ilk adımını teşkil etmektedir.

Beşinci aşamada; Bizans'ın resmen yeniden kurulmasını gündeme getirmektir. Ekonomik darboğazlarla boğuşan, dış baskı ve ambargolarla bunalan, PKK terör örgütü ve sözde dost komşularıyla boğuşan bir Türkiye bu safhada dünyayı karşısına alamayacaktır. PKK'nın Karadeniz'e çıkma çabalarının ve Lozan Antlaşması'nın sağladığı imkânlar çerçevesinde, mübadele yoluyla Anadolu'dan Yunanistan'a göç etmiş Gayrimüslim Osmanlı vatandaşlarının da çeşitli sebep ve yollarla tekrar Anadolu'ya gelmek istemelerinin arka planında dolaylı yoldan bu amaç vardır. $\mathrm{Bu}$ mücadele hiçbir yerden destek görmeyecektir.

Fener Rum Ortodoks Patrikhanesi tarafindan beş aşamalı plânın gerçekleştirilmesi maksadıyla aşağıda sunulan faaliyetler gerçekleştirilmiştir.

1. Evrensel olduğunu düşünen ve bu yönde gayret sarf eden Fener Rum Patrikhanesi bu düşüncesini, Şubat 1994'te İstanbul'da "Dünya Barışına Katkı Toplantısı" yapmış ve dünya kamuoyunda yankı uyandırmışıtır. Sonuç bildirgesinde İstanbul kelimesi kullanılmamış, "Boğaziçi Deklarasyonu" ismiyle yayımlanmıştır. $\mathrm{Bu}$ deklerasyonun İngilizce metninde, Türkçe metninde yeralmayan, Bartholomeos için "Ekümenik Patrik" unvanı kullanılmıştır. $\mathrm{Bu}$ durum dönemin Diyanet İşleri Başkanını yanılgıya düşürmüştür. Türkiye Patrikhane'nin Ekümenikliği konusunda son derece 
hassas olmasına rağmen, Patrikhane'nin yurtdıșındaki tanıtım faaliyetleri nedeniyle konunun boyutu daha da genişlemiş, Türkiye dış baskılara maruz kalmıştır. ABD Başkanı Clinton'ın Yunan asıllı danışmanlarından George Stefanopulos Patrikhane hakkında, “... misyonunu serbestçe yerine getirebilmesi için özel çabalar gösterdik ve göstermeye devam edeceğiz",52 açıklamasını yapmıştır. Bu dönemde ABD'nin Patrikhane'ye ilgisi artarak devam etmiştir. 24 Şubat 1994'te ABD Başkanı Clinton Başbakan Çiller'e özel bir mektup göndererek, Türkiye'nin Yunanistan'la arasındaki gerginliği azaltmak için Patrikhane'nin çalışmalarına ve uluslararası konuma kavuşmasına destek olması gerektiğini belirtmiştir. ${ }^{53}$ Clinton mektubunda şöyle der; “Yunanistan'la olan ilişkilerinizdeki gerilimi azaltmak için hükûmetiniz tarafindan bazı sembolik adımlar atılabilir... Bu sembolik adımlardan birisi, İstanbul'daki Rum Ortodoks Patrikhanesi olabilir ve bu kurumun işlerlik kazanması hususunda mevcut zor koşulları kolaylaştıracă̆ınızı ümit ediyorum."

2. Yine 1995 yılında Yunanistan'ın Petnas adasında "Vahiy ve Çevre Sempozyumu" düzenlenmiş ve toplantıya $\mathrm{ABD}$ Başkanının çevreden sorumlu yardımcısı ile İngiltere Prensi başta olmak üzere birçok devlet ve siyaset adamı katılmıştır. Sonuç bildirgesi, "Ekümenik Konstantinopolis Patriği” imza ve unvanıyla yayımlanmıștır.

3. Trabzon-Selanik hattında, 1997 yılında "Din-Bilim ve Çevre Sempozyumu" düzenlenmiş, bu sempozyuma da ABD Başkan Yardımcısı ve Çevre Bakanı siyasi destek vermişlerdir. Mali desteğini ise Dünya Bankası, BM Çevre Programı ve Yunan Ticaret Bankası üslenmişlerdir. Ayrıca Giritli bir armatör, Elefterios Venizelos adlı gemisini bu işe tahsis etmiştir. Sempozyumun açılış ve kapanış konuşmasında ilk dikkat çeken şey, Fener Patriğinin "Ekümenik Konstantinopolis Patriği" olarak takdim edilmesi olmuştur. Venizelos Gemisinde Karadeniz Bölgesinden Pontus diye bahseden tarihî bir harita dağıtılmıştır. Geminin Pontuslu Rumların göç ettiği Batum, Yalta, Odessa, Köstence, Varna ve Selanik'e gitmesi de dikkat çekicidir. O dönemde Trabzon halkı, geminin karaya yanaşmasını ve yolcuların şehre çıkmasını engellemiştir.

4. Avrupa Parlamentosu Patriğin ekümenik iddialarını desteklemektedir. Nitekim 24 Ekim 1996 tarihli bir kararlarında şu ifadelere

\footnotetext{
${ }^{52}$ Anadolu Ajansı Haberi, 9 Kasım 1993.

${ }^{53}$ Türk Dış Politikası, Ed. Baskın Oran, C.II, İletişim Yayınları, 1.Baskı Aralık 2001, İstanbul, s.459; Türk Dış Politikası, C.II, Ed. Baskın Oran, s.462; Hürriyet, 21 Ekim 1997. 
yer vermişlerdir. "Avrupa Parlamentosu, dünyanın her tarafindaki milyonlarca Ortodoks Hristiyan için Konstantinopolis'teki Patrikhane'nin önemini göz önünde bulundurarak, Türk yetkililerin ekümenik Patrikhane'nin, korunması konusundaki yükümlülüklerinin farkında olarak, ekümenik Patrikhane'nin ve diğer dinsel yerlerin binalarının korunması için gerekli önlemleri alması için Türk yetkililerine çağrıda bulunur."

5. Bu bağlamda Lozan Antlaşması'na, Anayasamıza, 3335 sayı ve 26.03.1987 tarihli yasaya göre, ayrıca 2908 sayılı Dernekler Kanunu ve Türk Medenî kanununa göre kurulan, vakıfların faaliyetlerini düzenleyen 25.07.1970 tarih ve 1066 sayılı tüzüğe göre Bakanlar kurulunun izni olmadan uluslararası faaliyet göstermemesi gereken Patrik, son y1llarda bunların tümünü çiğnemiştir. Anacak; $O$ dönem için gayri kanuni olan vakıflarla ilgili bu tür bazı faaliyetler, 20 Şubat 2008 tarihinde yeni Vakıflar Kanunu'nun çıarılmasından sonra kanuni duruma gelmiştir.

6. Patrikhane'nin en önemli karar meclisi olan ve 12 üyeden oluşan Sen Sinod Meclisi, Lozan Antlaşmasına göre sadece Türkiye Cumhuriyeti vatandaşlarından oluşması gerekmektedir. Ancak son yapılan atamalarla Amerikan, Yunan ve İtalyan vatandaşı olan Rum asıllı kişiler meclise dâhil edilmişlerdir.

7. AGITT zirvesinde Fener Patriği'ni dönemin ABD Başkanı ve eşi de ziyaret etmiştir. Patrik, Clinton'un eşine bir nişan vermiştir. Oysa Türkiye'de ancak bir devlet başkanı, konuk devlet başkanlarına nişan verebilir. Aynı şekilde Nisan 2000 tarihinde Alman Cumhurbaşkanı Johannes Rau'nun Fener Patrikhanesi'ni ziyaret ettiğinde, Patrik Alman Cumhurbaşkanına Aziz Andreas ${ }^{57}$ nişanı vermiştir.

8. Yunan Dışişleri Bakanı Yorgo Papandreau,10 Ekim 2001'de, Türkiye ziyaretinde Fener Patriği ile özel bir görüşmede bulunmuştur.

9. Bartholomeos'un 10 Ocak 2002 tarihinde İran'a yaptığg ziyarette, İran Kültür Bakanı ile İran ve Yunanistan arasında kültürel ilişkilerin geliştirilmesini öngören bir antlaşma imzalamıştır.

10. Fener Rum Patriği, 04 Mart 2002 tarihinde ABD'deki Ortodoks Başpiskoposluğunun 80. yıldönümü kutlamalarına katılmak maksadıyla ABD'ye gitmiş ve bir gün sonra ABD Başkanı ile görüşmüştür. Heybeliada Ruhban Okulu'nun açılmasıyla ilgili Türkiye'yi ABD Başkanına şikâyet ettiği daha sonra yabancı basından öğrenilmiştir.

\footnotetext{
57 Aziz Andrew (Andreas); Hz. İsa'nın ilk havarisidir ve İstanbul ve Anadolu'ya gönderilerek buraların Hristiyanlaştırılması görevini üstlenmiştir. Fener Rum Patrikhanesi'nin kurucusu olduğu iddia edilen havaridir. Mehmet Çelik, Fener Patrikhanesi'nin Ökümeniklik İddiasının Tarihî Seyri (325-1453), Akademi Kitabevi, İzmir, 2000, s.153.
} 
11. Patrik 3,5 yılda tam 23 ülkeyi ziyaret ederek bir dünya turu gerçekleştirmiştir. Patriğin bu seyahatleri Türk Hava Yolları'nın değil de, Yunan Olimpik Hava Yolları'na ait ve üzerinde "Çift Başlı Kartallı Bizans Bayrağı" bulunan bir uçakla yapmış olması da ayrıca dikkat çekicidir. Patriğin bu ziyaretler ve temaslarla ulaşmak istediği hedef, Bizans Dönemine benzer bir şekilde bütün Ortodoksları, Fener Patrikhanesi çatısı altında toplamak, Türk resmî makamlarının tepkisizliğinden de faydalanarak, resmî ve gerçek olmayan bu "ekümenik" sıfatına "hükmi şahsiyet" kazandırmaktır. $^{58}$

12. Arka arkaya, Anadolu'nun çeşitli yörelerinde terkedilmiş kiliseler restore edilip Patrik tarafindan ayinler düzenlenmektedir. Hatta bazen açık alanlarda da bu ayinler yapılmaktadır. ${ }^{59}$ Anadolu'da Hristiyan cemaat olmadığı için otobüslerle İstanbul'dan ve Yunanistan'dan bu ayinlere cemaat taşınmaktadır (Gidilen yerler; Fethiye, Ayvalık, Altınoluk, İznik, Kayseri, Ürgüp, Antakya, Urfa ve İzmit'tir). ${ }^{60}$

13. Patrik Yunan gazetesi Etnos'a 2002 y1lında verdiği bir demeçte “Hristiyanlar Anadolu'ya yerleşebilir, Türkiye'nin AB üyeliği çerçevesinde Anadolu'da önceden var olmuş Hristiyan toplumlar eskiden yaşadıkları bölgelere yerleştirilirse o zaman Patrikhane de o bölgelerde bulunan kiliselerin yeniden ayine açılmasını düşünebilir..." demiştir.

14. Uzun zamandan beri Patrikhane çevresinde Türk ve Rum iş adamlarınca alınan gayrimenkuller önce hibe yoluyla azınlık vakıflarına, daha sonra da Patrikhane'ye devredilmektedir. $\mathrm{Bu}$ kapsamda Fatih belediyesi, $\mathrm{AB}$ ve UNESCO işbirliği ile hazırlanan "Balat-Fener Rehabilitasyon Projesi” dikkat çekicidir. Sur içi İstanbul'un Bizans ve Hristiyan kimliğini öne çıkarıp, tarihî zemine uygun olarak yeniden düzenlenmesi ve bir dünya metropol kültür ve din merkezi olarak eski Ortodoks Konstantinopolis'in yeniden ihya edilmesi plânlanmaktadır. ABD özellikle 21. Yy.da bu çalışmalara hız vermiştir. Bu projeyle ABD'nin, yaklaşık 270 milyon Ortodoks dünyasını Fener Patrikhanesi'ne bağlayarak, kontrol altında tutmak istemesinin yanında, ayrıca, ekonomik olarak Karadeniz'in enerji nakil hatları üzerinde söz sahibi olmak ve kontrol etmek istemesi yatmaktadır.

\footnotetext{
${ }^{58}$ M.Süreyya Şahin, Türkiye'deki Patrikhaneler, İlke Yayıncılık, İstanbul, 2003, 148.

${ }^{59}$ Turgay Tüfekçioğlu, Türkiye ve Şeytan Üçgeni, Hat Matbaası, Bursa, 2001, s.178.

${ }^{60}$ Ebetteki Türkiye'deki dinî tolerans sebebiyle bu ayinler hoş görülebilir ki, bugünkü yönetim de bu yönde adımlar atarak, çeşitli din ve inançlara mensup Türk vatandaşlarının ibadetlerini serbestçe yapabilecek tüm tedbirleri almaktadır. Ancak bu faaliyetlerin nihai amacı Anadolu'yu müteveffa papanın son vasiyetinde olduğu gibi aslına döndürmek amacına matuf değilse.
} 
15. Patrikhane, sur içi Konstantinopolis'in gelecekteki oluşumuna gayrimenkuller alarak zemin hazırlarken, sur içindeki meskûn Türk-İslâm nüfusunun azalmasının ileride bir tehlike doğurabileceği düşünülmektedir. 1950'lerden itibaren kademeli olarak sur içi iş merkezine dönüştürülmekte ve meskûn nüfus sur dışındaki semtlere taşınmaktadır.

16. Yunanistan, Fener Patrikhanesi'nin ekümeniklik sıfatının uluslararası alanda tanınması amacıyla, 2004 yılında beş günlük bir ziyaret için Patrik Bartholomeos'u Küba'ya göndermiştir. Bartholomeos Küba'da, Yunanistan'ın gönderdiği mozaik, şamdan ve ikonlarla, 1959 devriminden bu yana ilk defa restore edilen Ortodoks kilisesini dinî hizmete açmıştır. Havana'da Bartholomeos'un bu ziyareti, Patrikhane'nin Atina desteğiyle evrenselleşme çabası olarak görülmektedir. Yunanistan ise böylece, bir yandan Fener Rum Patrikhanesi'nin uluslararası alanda tanınmasını ve evrenselleşmesini sağlarken, bir yandan da Patrikhane üzerindeki gücünü pekiştirmiş, ayrıca Küba ile ilişkileri sağlamlaştırmış oldu.

17. Patrikhane'nin ekümeniklik çalışmalarıyla ilgili son attığı adım, 24 Mayıs 2005 tarihinde Kudüs Patriği I. İrineos'u yargılamak için kurmuş olduğu "Şeriat Mahkemesi"dir. Fener Rum Patrikhanesi; Lozan Antlaşmasını, Anayasamızı ve yasalarımızı hiçe sayıp, kendisine bağlı olduğunu kabul ettiği kiliselerle "Hristiyan Şeriatı"na göre mahkeme kurarak, Kudüs Patriği I. İrineos'u yargılamıştır. Kudüs Patriği, Patrik Bartholomeos'un başkanlık ettiği ve Sırp, Romanya, Gürcistan, Antakya, Arnavutluk, Atina, Finlandiya, Polonya, Prag, Kıbrıs, Moskova Kilise temsilcilerinin katıldığı toplantıda, Kudüs'te kiliseye ait bazı taşınmazların İsrail'e uzun süreli (190 yıllığına) kiraladığı iddiaları ve bu kararları alırken Kudüs Kilisesi Sen Sinod Meclisine danışmadığı iddiaları ile yargılanmıştır. Yargılama Kudüs Patriği aleyhine sonuçlanmıştır. Artık, Kudüs Patriği’nin ad1, kilise ayinlerinde okunmayacak, Patrik, resmî olarak tanınmayacaktır. ${ }^{61}$

Ortodokslar, Türkiye Cumhuriyeti'nde kendi dinî mahkemelerini kurmuşlar. Bartholomeos, statü olarak Türkiye'de bulunan azınlık kilisesinin başpapazı olan bir kişidir. Yargılanan Kudüs Patriği, hırsızlık, dolandırıcılık gibi adi suçlardan yargılanmıştır ve başka bir ülkenin vatandaşıdır. Adi suçtan dolayı başka bir ülke vatandaşı, Türkiye Cumhuriyeti sınırları içinde hangi hakla yargılanmaktadır. Bu, Bartholomeos'un ekümenik olma hayaliyle, 15 Ortodoks Papazı ayağına çağırarak, Lozan Antlaşmasını ihlâl etmesidir. Türkiye, 1923 yılından beri laik bir ülkedir. Şeriat mahkemesi olmayan bir ülkede Hristiyan şeriat mahkemesi kurulmuştur. Bu, Vatikan gibi bağımsız bir ülke olmak için adım adım ilerlemenin çabasıdır. Vatikan, bağımsız bir ülkedir, mahkeme kurabilir. Ancak, Fener Rum Kilisesi, Fatih

\footnotetext{
${ }^{61}$ Vatan, 25.5.2005.
} 
Kaymakamlığı'na bağlı bir kurumdur, böyle bir hakkı yoktur ve yaptığg Türkiye Cumhuriyeti yasaları önünde bir suçtur. $\mathrm{Bu}$ duruma tepki gecikmemiştir. "Zirve" adı altında din mahkemesi devam ederken, kendilerini "Fener-Balat Sakinleri" olarak tanitan bir grup protesto yapmıştır. Ortodoksların İstanbul oyununa Ankara da sessiz kalmamıştır. Önce zamanın Devlet Bakanı Mehmet Aydın, ardından Sivil Toplum Örgütleri yaşananlara sert şekilde tepki göstermiştir. ${ }^{62}$

Bir kere mahkeme kurulduktan sonra, meydanı boş bulan Patrikhane, sırayı Türkiye'nin yargilanmasına getirecektir. Kibrıs konusunda, Rumların ve Ermenilerin toprak ve tazminat talepleri ile ilgili konularda Türkiye'nin yargilanmasına sira gelecektir. Merkezi Antalya'da bulunan Noel Baba Vakfı Başkanı Muammer Karabulut tarafından, Fener Rum Patrikhanesi hakkındaki konuya ilişkin suç duyurusu dilekçesi Ankara Cumhuriyet Savcılığına verilmiştir. Vakıf Avukatı Süleyman Çetin yaptığı açıklamada; "Fener Rum Patrikhanesi, TC'nin tüm yasalarını çiğneyerek Ortaçă̆'dan kalma bir zihniyetle, Kudüs Patriğini yargllamak üzere bugün İstanbul'da şeriat mahkemesi kuracaktır. Bu fiilî durum Patrikhane tarafindan resmen açıklanmasına rağmen, Türkiye'de gerek resmî makamlar, gerekse sivil toplum kuruluşlarınca ne yazlk ki yıllardır yapılan propagandaların da etkisiyle yeterince anlaşılmamıştır. Böylesi bir mahkeme ancak din devletlerinde kurulur" diyerek konuya tepkilerini vurgulamiştır. $^{63}$

Esasen Patrikhane ile Yunanistan'1, ayrı olarak düşünmek mümkün değildir. Patrikhane Yunanistan'ın, Türkiye'deki "ileri karakolu", "Megali İdea'nın sadık hizmetkârıdır". Lozan Konferansı'nda Venizelos'un, Patrikhane'nin "posa halinde" olsa bile, Türkiye'de kalmasını ısrarla istemesi de bundandır. ${ }^{64}$

\section{Fener Rum Ortodoks Patriği Hukuken ve Dinen Ekümenik mi?}

Kişinin veya bir makamın ekümenik olması için bazı şartları yerine getirmesi gerekmektedir. Bu şartlar şunlardır:

1. Ekümenik olan bir makama o ülkedeki veya dünyadaki çeşitli etnik gruplara mensup din adamlarının da seçilip gelebilmesi mümkün olmalıdır.

2. Ekümenik olduğu iddia edilen bir makama gelecek kişiyi seçecek konsey, dinî meclis de çeşitli uluslardan tam yetkili din adamlarından oluşmalıdır.

3. Ekümenik bir dinî liderin cemaati de çeşitli uluslardan meydana gelmelidir.

\footnotetext{
${ }^{62}$ TGRT Haber, 25 Mayıs 2005.

${ }^{63}$ Sabah, 24 May1s 2005, www.sabah.com.tr/18.10.07.

${ }^{64}$ Musa Süreyya Şahin, Türkiye'deki Patrikhaneler, İlke Yayıncılık, İstanbul, 2003, s.150
} 
4. Ekümenik olduğunu iddia eden kurum ya da kilise, bulunduğu ülkenin millî erkinin emrinde ve yasalarının denetiminde olmamalıdır.

5. Ekümenik olan kişinin göreve gelmesi ve görevden alınması bölgesel hükümet tarafından yapılmamalıdır.

6. Dinî açıdan ekümenik olan bir kişi ya da kurumun etki alanı siyasi sınırlara bağımlı olmamalıdır.

7. Ekümenik olduğu iddia edilen kilisenin, kendisine bağlı olan daha alt seviyedeki kiliseler, diğer kiliseler tarafindan da kabul edilmelidir. Bu mantık içerisinde, tüm dünya dinî ve siyasi otoriteleri tarafından ekümenik olarak kabul edilen Vatikan Katolik Kilisesi ile Fener Rum Ortodoks Patrikhanesi'ni kıyaslayalım.

a. Vatikan'daki Papa değişik milletlere ve etnik gruplara mensup kişiler arasından seçilir. Fener'deki Patrik, 17 asır boyunca hep Rum-Yunan asıllılar arasından seçilmiştir.

b. Vatikan'daki Papa'yı seçen Kardinaller de değişik millet ve etnik gruplara mensuptur. Patriği seçen Metropolitler Rum ve Yunan kökenlidirler.

c. Vatikan'daki Papa'nın cemaati bütün dünyadaki değişik etnik gruplardan Katoliklerdir. Patriğin cemaati ise, Rum-Yunan kökenli Ortodokslardir.

d. Papalığın kapsama alanı, ülkelerin sınırlarının değişmesi, ya da ülkelerin kurulmasına bağlı değildir. Patrikliğin kapsama alanı ise, Bizans İmparatorluğu, Osmanlı İmparatorluğu ve Türkiye Cumhuriyeti dönemlerindeki ülkelerin hudutları ile sinırlıdır.

e. Papa'nın seçilmesinde veya görevden alınmasında İtalyan makamları onay makamı değildir. Fener'deki Patriğin seçilmesinde veya görevden alınmasında Türkiye'nin İstanbul Valisi onay makamıdır.

f. Papa'yı İtalyan makamları denetleyemezken, Patriği Türkiye Cumhuriyeti Devleti makamları denetler.

g. Papa'nın yetkileri, siyasi otoritelerce sınırlandırılamazken, Patriğin yetkileri tarihî süreci içerisinde siyasi otoritelerce bazen daraltılmış, bazen genişletilmiştir.

h. Roma Kilisesi kendini İmparatorların üstünde bir güç olarak görmüştür. Fener Kilisesi, Bizans, Osmanlı ve Türkiye Cumhuriyeti dönemlerinde İmparatorların ve Devlet Başkanların altında, denetiminde olmuşlardır. 
1. Papa, Patrik üzerine Haçlı Seferleri düzenlemiş, ondan güçlü olduğunu göstermiştir.

i. Papa haç taşır, Hristiyanlıkla ilgili olamayan aksesuar taşımaz; Patrik Ortodoks Haçı ile birlikte Bizans Kartalı gibi millî-etnik semboller taşır.

j. Papa'nın ikamet ettiği Roma'da bağımsız başka Katolik kiliseleri bulunmaz. Patriğin ikamet ettiği İstanbul'da Ortodoks mezhebine mensup, değişik etnik gruplara ait bağımsız kiliseler mevcuttur.

k. Papa İtalyan ordusunda askerlik yapmazken, Patrik Türk ordusunda askerlik yapar. ${ }^{65}$

1. Papa, İtalya'daki yerel ve genel seçimlerde oy kullanmazken; Patrik, Türkiye'deki genel ve yerel seçimlerde oyunu kullanır. ${ }^{66}$

m. Papa'nın Vatikan Bayrağı Papalığı temsil eden dinî bir bayraktır. Fener'deki Patrik, korsan olarak Çift Başlı ulusal Bizans Bayrağını kullanmaktadır.

n. Papa'nın İsviçreli askerlerden oluşan bir Muhafız Birliği vardır. Tarihî kıyafetler giyen bu muhafız Birliği, Papalığın bağımsız ve ekümenik olduğunu gösteren en önemli göstergelerinden biridir. Patrik ise, Bizans ve Osmanlı dönemlerinde o devletlerin askerleri, Türkiye Cumhuriyeti döneminde Türk polisi tarafından korunmaktadır.

o. Papa, Amerikan Forbes Ekonomi Dergisi tarafindan 2010 yılının dünyada en güçlü 5. lideri seçildiği halde, Patrik ise dünyadaki 68 güçlü liderler Forbes listesine bile girememiştir. ${ }^{67}$

Ö. Papa, Katolik Kilisesinin tek lideridir ve Katolik Hristiyanlar üzerindeki tartışılmaz yere sahiptir. Fener Patriği, bağımsız 15-20 bağımsız Ortodoks Kiliselerinden birinin dinî lideridir, kendilerince "eşitler arasında birinci” şeklinde kabul edilir.

p. Katolik Kilisesi'ndeki Papa, bilgi ve kararları itibarıla "yanılmaz" kabul edilir. Açıklamaları dikkatle takip edilir. ${ }^{68}$ Rum Ortodoks Patriği önemli konularda tek başına karar alamaz. "Sen Sinod" (Kutsal Meclis)'le birlikte hareket etmek zorundadır.

r. Papa iki kimliklidir. Hem Devlet Başkanı hem de Katolik Dünyası'nın deyimiyle “Tanrı'nın Vekili”dir. Patrik tek kimliklidir. Kilisenin başıdır.

${ }^{65}$ Hürriyet, 22 Aralık 2009.

${ }^{66}$ Hürriyet, 9 Kasım 2009; Cumhuriyet, 15 Mayıs 1950.

${ }^{67}$ Milliyet, 5 Kasim 2010.

${ }^{68}$ Hürriyet, 21 Kasim 2010. 
Sayılan bu faktörlerden anlaşılmaktadır ki; dünyadaki bağımsız kiliseler arasında gerçekten ekümenik (evrensel) olan tek kilise Vatikan'dır. Vatikan'daki Papa, ekümenik unvanını kullanmaya gerek görmeyecek kadar evrenseldir. Patrik ise, yereldir. Rumların dinî lideridir. Türkiye'ye ve bazı bağımsız Ortodoks Kiliselerine karşı "ekümenik" olduğunu umutsuzca iddia etmektedir. Aslında ekümenik Patriklik de; nüfus, kapsama alanı, millet çeşitliliği açılarından üç bin Ortodoks'un Patriğinden ziyade, 200 milyon Ortodoks'un Patriği Moskova Patrikliğine yakışmaktadır. ${ }^{69}$ Zaten Rus Ortodoks Kilisesi, "1453 yllında Türkler İstanbul'u fethedince Ortodoksluk bitmiştir. Ve bu tarihten itibaren Ortodoksluğun yeni merkezi Rusya'dır" diyerek kendisini kuzeyde yükselen "Yeni Roma", Moskova'yı mukaddes toprak, Roma'nın varisi olarak kabul ederek karşı proje geliştirmeye çalışmaktadır. ${ }^{70}$

Türkiye, Patriğin Ekümenik sıfatını kabul ettiği takdirde neler olur?

Araştırmac1 yazar Aytunç Altındal, Yeniçağ'da "Casus Yuvası Patrikhane" başlı̆g 1 altında yayımlanan makalesinde şöyle demektedir: “ABD'nin Büyük Ortadoğu Projesi var. Bu projede Patrikhane koçbaşı statüsünde. Bu nedenle Patrikhane'ye önce Vatikan tarafindan bazı kutsal emanetler verildi. Çünkü bu Patrikhane'nin elinde hiçbir kutsal emanet kalmamıştı. Dördüncü haçlı seferi sırasında hepsi alıp götürülmüştü. Dolaylsıyla birkaç tane kutsal emanet verilerek kiliseye yeniden bir merkez temin edilmeye çalışllyyor. Kim temin etmeye çalışlyor. Tabii ki ABD ve Israil. Buradan baktı̆̆ımız zaman, geçen şubat ayında, aslında beşi Yunan vatandaşı olan ama değişik ülke pasaportu taşıyan altı yabancı Sen Sinod'a metropolit olarak atandl. Ben o sırada Abdullah Gül'e konunun çok tehlikeli olduğunu defalarca anlattım. Gül, bana 'Evet kilise haddinden büyük işlere kalkışıyor. Takip ediyoruz ve de edeceğiz' dedi. Bugüne kadar herhangi bir sonuç çıkmadı̆̆ına göre herhalde halen takip etmekteler. Şimdi bu altı yeni üye, Kıbrıs veya başka bir ülke konusunda Patriğe ekümeniklik yetkilerini kullanma hakkı veriyor. Bu da bizim anlattıklarımızı zaten doğruluyor. Çünkü eğer Türkiye Cumhuriyeti, bu adamın ekümenikliğini kabul ederse, iç hukuk adı altında, aynı yetkileri bu defa Türkiye için kullanacak. Ve Türkiye'deki mevcut siyasal yapı dışına çıkarak, Hristiyan şeriat yasaların kendi hakkıymış gibi kullanmaya başlayacak. Kıbrıs meselesinin önemi buradadır. Yani Kıbrıs veya başka bir kilise, bu hiç fark etmez. Bu gelişme onun ekümenikliğinin Türkiye'de kabul ettirilmesidir. Türkiye Cumhuriyeti,

\footnotetext{
${ }^{69}$ M. Özekin, Fener Rum Ortodoks Patrik'i Ekümenik mi?, s.19-21.

${ }^{70}$ Mehmet Aydın, "Batı ve Doğu Hristiyanlığına Tarihî bir Bakış", AÜIF Dergisi, Ankara, 1985, Say1: 27, s.146-147.
} 
bunu şu veya bu şekilde kabul etmesi halinde; adam diyecek hakl olarak 'Ben ekümenik miyim? Ekümenikim. Öyleyse bana ekümene gösterin. Bana bir yer gösterin. Benim ekümenikliğim nereden geçer?' Işste devlet içinde devlet, Vatikan gibi oluşum bu demektir. Onun için Kıbris veya başka bir kilise meselesi hiç fark etmez. Bunların bir tanesini, şu veya bu şekilde Türkiye ile ilgili gözükmese bile, ilk etapta aldı̆̆ı kararlar Türkiye'yi bağlar mahiyette olacaktır." ${ }^{\text {"71 }}$

Yıldız Teknik Üniversitesi Öğretim Üyesi Elçin Macar da Patrikhane'nin ekümeniliği ile ilgili olarak; „Patrikhane'yi siyasallaştıran Osmanlı'dır. Vârisi olan yeni Türk Devleti de bu siyasiliğini ortadan kaldırır. Ancak bu onun ekümenikliği ile ilgili değildir. Çünkü, yalnızca ,ekümeni=siyasi' demek değildir. Bu dinî unvanı tanımamak da diğer Ortodoks kiliselerinin sornudur. Öyleyse sorun Patrikhane'nin ekümenikliği değil, siyasete bulaşıp bulaşmamasıdır. Elbette laikliğin gereği budur."ㄱ2 demektedir. Burada Sayın Macar'a şunları hatırlatmak isteriz. Öncelikle, Osmanlı Patrikhane'yi siyasallaştırmadı, kendisine bir kamu görevi ve yetki vermek suretiyle, Patriği Rum halkının dinî fonksiyonlarından sorumlu bir tebaa haline getirdi. Patrik kendisi „Bizans Hayali“ni emel edinerek siyasete dalmıştır. Her Papaz bir ajan ve „Megali İdea“cı kesilerek din işlerini tamamen ihmal etmiştir. ${ }^{73}$ Osmanlı Döneminde Patrik ekümenik değil, yetkileri Osmanlı hakimiyeti ile sınırlı idi. Türkiye Cumhuriyeti'nde ise, varolmayan bir yetkiyi alamaz. Ayrıca, ekümeniklik sadece Ortodoks dininin, Ortodoks kiliselerinin bir iç sorunu değildir. Bu sorun aynı zamanda Türkiye'nin bir sorunudur. Çünkü Patrik Türkiye'de ikamet eden, Türk kanunlarına tâbi bir Türk vatandaşıdır. Yaptığı ve yapmadığı her şeyin izdüşümü Türkiye'ye olacaktır.

Atatürk milliyetçiliğini kabul etmiş olan ve Misak-1 Millı̂'yi vazgeçilemez temel prensip kabul eden Türkiye Cumhuriyeti'nin kendi sınırları içinde, hedefleri ve temel stratejileri ile çelişen, yeni bir güç odağını kabulü söz konusu olamaz. Bu durumu daha açık olarak anlatmak gerekirse; Türkiye Cumhuriyeti'nin bir kurumu olan adalet sistemimiz, YÖK, MEB, Sağlık Kuruluşlarımız, Diyanet İşleri Başkanlığımız, Güvenlik Örgütlerimiz vs. kendilerini Türkiye Cumhuriyeti kanunlarının ve millî bütünlüğünün üstünde görmeleri nasıl ki mümkün değilse; Fener Rum Patrikhanesi de bu kuruluşlar gibi davranmak ve diğer milletlerin kurumları ile işbirliğine girerken Türkiye Cumhuriyeti'nin temel prensiplerine uymak zorundadır.

\footnotetext{
71 Aytunç Altındal, “Casus Yuvası Patrikhane”, Yeniçă̆, 10 Kasım 2005; www.biroybil.com/09.11.2007.

${ }^{72}$ E. Macar, Cumhuriyet Döneminde Istanbul Rum Patrikhanesi, s.274.

${ }^{73}$ Kadir Misıroğlu, Yunan Mezalimi, Türkün Siyah Kitabı, Sebil Yayınevi, İstanbul, 1966, s.179.
} 
Patrikhanenin tüm dünya Ortodokslarının merkezi (Yeni Vatikan) olmak iddiası TC'nin temel stratejileri ve prensipleri ile uyuşmamaktadır. $\mathrm{Bu}$ açıdan, Patrikhane'nin 1994'te yaptığı hata hiçbir şekilde kabul edilemez: 1994'te Patrikhane tarafindan tertiplenen toplantı öncelikle "Konstantinopolis toplantısı" adıyla gerçekleştirilmek istenmiş; devletin itirazı üzerine "Boğaziçi Toplantısı" olarak yapılmıştır. Aynı toplantının sonuç bildirgesi İngilizce ve Türkçe olarak hazırlanmıştır. İngilizce metinde yer alan ve Patriğe atfedilen, "Ben Konstantinopolis'deki ekümenlik tahtının varisiyim" ifadesi Türkçe metinde yer almamıştır. $\mathrm{Bu}$ ayıp hâlen düzeltilmemiştir. $^{74}$

Patrikhane'nin ekümenikliğinin kabul edilmesi ile ortaya çıkan bir diğer sorun Hristiyanlara tanınacak bu hakkın Müslümanlara tanınıp tanınmayacağıdır. \%99'un üzerinde nüfusu Müslüman olan bir ülkede Müslümanların Hristiyanlara göre özgürlük ve haklar açısından ikincil bir konuma gelmenin getireceği çelişki ve durumun nasıl aşılacağıdır. Mesela, Diyanet İşleri Başkanı'na özerklik tanınması $;{ }^{75}$ Ortodoks, Ermeni, Yahudi dinî liderleri gibi dünyaya açılması şeklinde bir konunun gündeme gelmesi durumunda sorunun nasıl çözümleneceği... $\mathrm{Bu}$ durumda, Türkiye'nin laikliğinin ortadan kalkması tehlikesi ortaya çıkacaktır. Patrikhane, nasıl mahkeme kurduysa, Türkiye'deki İslâmi cemaatler de kendi iç hukukunu uygulamak için mahkemeler kuracak; yarın bir başkası çıkıp halifeliğini ilân edecektir. Bu, Türkiye Cumhuriyeti'nin bekası için çok tehlikeli bir durumdur.

Bütün bunların yanında Fener Patrikhanesi ekümenik olmak suretiyle, Vatikan gibi bir dinî devlet olma yolunda çizdiği plânı adım adım uygulamaya sokuyordu. Devlet olma yolunda atılacak en önemli adım bir araziye sahip olmaktı. Bu maksat için Fener Patrikhanesi civarında bulunan Türklere ait ev ve işyerleri çok yüksek ücretlerle satın alınmaya başlanmıştır. $\mathrm{Bu}$ konuda Patrikhane basın sözcüsü Tarabya Metropoliti Harissiadis "Evet Patrikhane'nin Fener'de mülk edindiği doğrudur. Bunlar birkaç balıkçı barakasından ibarettir. Bunu bizim gizlediğimiz yok. Patrikhane'de çalışan yoksul ve çok uzakta oturan müstahdemler için edinilmiştir." diyerek itirafta bulunmuştur. ${ }^{76}$ Oysa Patrikhane'nin birkaç balıkçı barınağı dediği arazi 4000 $\mathrm{m}^{2}$ 'dir. Patrikhane'nin İstanbul Büyükşehir Belediyesine ait $600 \mathrm{~m}^{2}$ 'lik araziyi de yıllardır kullandığı Fatih Belediyesi'nce teşkil edilen bir heyetçe

\footnotetext{
74 Kenan Erzurumluoğlu, "Patrikhane ve Pontus Dosyası: Kin Kapısı", www.ifsa.blogcu.com/15.11.2007.

${ }^{75}$ Aydın Ömeroğlu, Türk Devleti ve Rum Patrikhanesi, Kim Kimin Dostu? Avcı Ofset, İstanbul, 1995, s.83.

${ }^{76}$ Musa Süreyya Şahin, "Fener Rum Ortodoks Patrikhanesi”, Türkiye Diyanet Vakfi İslam Ansiklopedisi, XII, İstanbul, 1995, s. 322-323.
} 
tespit edilmiştir. Bu durumda Patrikhane yaklaşı $11.000 \mathrm{~m}^{2}$ 'lik bir araziye sahip bulunmaktadır. $O$ halde yeni yeni istimlâkler ne maksatla yapılmaktadır. Bunlar Vatikanlaşma yolunda atılan adımlar değil de nedir? ${ }^{77}$ Ayrıca 20 Şubat 2008 tarihinde çıkarılan yeni Vakıflar Kanunu ile daha evvelden gayri kanuni addedilerek Vakıflar Genel Müdürlüğü'ne devredilen bazı arazileri ve diğer taşınmazları Patrikhaneye iade edilmiştir. ${ }^{78}$

Patrikhane; üzerine aldığı dinî ve siyasi görevleri yerine getirebilmek amacıyla, Fener semtinde merkez binasında oldukça kalabalık bir kadro ile çalışmaktadır. Dinî yardımcıların dışında, Hukuk danışmanı, özel doktoru, mimarı, mühendisi, hesap uzmanı, film ve fotoğrafçısı, gazetecisi ile birlikte sayıları yüzü aşan teknisyenler kadrosu, Patrikhane'nin diğer unsurlarını teşkil etmektedir.

Patrik ekümeniklik konusundaki faaliyetlerini sürdürürken hiç de gizli saklı bir şey yapmıyor. Patrikhane, resmî web sitesinde, yayımladığı broşürde "ekümenik" olduğunu açıkça vurgulamaktadır. ${ }^{79}$ Türkiye'de bulunan Patrikhane "de facto" olarak kendisine bağlı Amerikan Ortodoks Kilisesini merkez olarak kullanmakta, böylelikle hem Amerika'daki Rum lobisinin dikkatini çekebilmekte, hem de Amerikan yönetimine yönelik yayınlar yapabilmektedir. http://www.patriarchate.org adresli site son derece ilginç bilgiler içermektedir. Öncelikle Patrikhane'nin ismi bizim bildiğimiz gibi Fener Rum Patrikhanesi olarak değil, "Konstantinapol Ekümenik Patrikliği" olarak görülüyor. Patrikhane'nin tarihçesinde, "Vatikan Roma Katolik Hristiyanlığın kalbidir. Konstantinapol Ekümenik Patrikliği de Ortodoks Hristiyanlığın kalbidir." Bu sözlerin devamında da Patrik Bartholomeos'un 270 milyon Ortodoksun lideri olarak Patrikhane'nin Avrupa'nın bütünlüğünü sağlamadaki küresel rolünün farkında olduğu belirtiliyor. Bütün bunların yanında Amerika ise, küresel güç olmanın ideolojik aygıtlarından biri olan Ortodoks Kilisesinin ekümenik yapılanmasını desteklemekte ve Osmanlının bir İslâm-Ortodoks devleti olduğunu savunmaktadır. Bugün de Fener Rum Patrikhanesi'nin bu İslâmOrtodoks kardeşliği içinde örgütlenmesinin yolunu açarak İslâm ve Ortodoks dünyasındaki egemenliğini öne çıkarmaktadır.

\section{Sonuç}

Sonuç olarak Fener Rum Ortodoks Kilisesi, tarihî süreci göz önünde bulundurulduğunda, dinen Patriklik statüsünde bile değildir. Zira bir zamanlar Patriklik sıfatını taşıması, İstanbul'un başkent olması sebebiyle;

\footnotetext{
${ }^{77}$ Türkiye, 1 Aralık 1993; Aksiyon Dergisi, Say1: 30, s.29.

${ }^{78}$ E. Yalçın, Son Haçlı Kalesi: Heybeliada, s.192-225.

${ }^{79}$ Resmî Broşür: Ekumenical Patriarchate, Stephen and Catherin Pappas Boston, MA; USA(tarihsiz); Resmî Web Sitesi:www.patriarchate.org/28.05.2007.
} 
yani siyasi zaruretlerdendir. Bugün İstanbul'un başkent olmaması, bu statünün dahi tartışma konusu olarak gündeme getirilmesi, başta diğer Grek Kiliselerinin görevidir. Hele hele "ekümenik" yani "Evrensel Patriklik" iddiasının gündeme getirilmesi, tamamen siyasi amaçlara matuf bir aldatmacadır. ${ }^{80}$ Onuncu yüzyıldan günümüze kadar devam eden 1000 yıllık süreçte Fener Rum Ortodoks Patrikhanesi'nin Ekümeniklik sıfatı hiçbir zaman gündeme getirilmemiştir. Türkiye açısından Patrikhane'nin statüsü Lozan'da belirlenmiştir. Lozan Konferansı'nda hiçbir azınlıktan bahsedilmemiş ve herkes eşit kabul edilmiştir. Bu çerçevede nasıl ki bir Diyanet İşleri Başkanı, bir müftü yalnız Müslümanları temsil eden dinî yetkili olup devletin bir memuru olarak devlet üstünde bir kişiliğe sahip değilse, Fener Rum Patriği de devlet üstünde bir kişiliğe sahip değildir ve kendi başına hareket edemez.

Hatırlanacağı üzere Patrikhane, dünya Ortodoks Âlemi için değil, mübadele sonrası İstanbul'da kalan Rum azınlığın dinî vecibelerini yerine getirmesine yardımcı olmak amacıyla bırakılmıştır. Lozan Antlaşması'nın 45. Maddesine göre, azınlıklarla ilgili olarak mütekabiliyet-karş1lılık ilkesi benimsenmiştir. Türkiye, halen Rum azınlıktan bahsetmesine rağmen, AB'nin üyesi olan Yunanistan Hükûmeti, ülkesinde Türk olmadığını, sadece Müslüman azınlık olduğunu ifade etmektedir. Lozan'ın mütekabiliyet esasına göre hareket ederek, Türkiye'deki Rum azınlıktan da bahsedilmemeli ve Fener Rum Ortodoks Patrikhanesi'nin ismi de "İstanbul Ortodoks Patrikhanesi" (veya Kilisesi) olmalıdır. Yunanistan, seçilen müftüyü atamayıp, kendi seçtiği müftüyü atadığı gibi; Türkiye de Patrikhane'nin başına Türkiye'deki Ortodoks dinî hizmetlerini yürütecek bir Türk Ortodoks Patrik (veya papaz) getirmelidir. Türkiye, Lozan Konferansı'nda Patriğin siyasi faaliyetlerinden şikâyetçi olarak, şimdi Patrikten siyasi yardım istemesi, Türkiye'nin geçmişteki tecrübeleriyle tutarlı değildir. TürkiyeYunanistan ilişkileri ya da $\mathrm{AB}$ gibi konularda Patrikhaneyi kullanmak, onu siyasetin içine çekmek anlamına gelir ki, bu da Patrikhane'nin ekümenikliği yolunda almak istediği önemli bir mesafedir.

Diğer yandan, Türk kamuoyunda gündeme gelen Rusya, Sirbistan ve Yunanistan tarafından "Türkiye'nin Ortodoks çemberi içine alınması" ve Türkiye'ye karşı bir "Ortodoks İttifakı” kurma gayretlerinin merkezinde Patrikhane'nin olduğuna dair işaretler mevcuttur. ${ }^{81}$ Bartholomos, "Moskova bunu gündeme getirdi ama ben karşı çıktım" ${ }^{\prime 2}$ diyerek, iddiaların hayal ürünü olmadığını açıklamış olur. Ortodoks İttifakı diye bilinen Fatih'in Bizans'1 fethinden günümüze kadar canlı kalan bu fikir emperyalistlerin

\footnotetext{
${ }^{80}$ M. Çelik, Fener Patrikhanesi'nin Ökümeniklik İdiasının Tarihî Seyri (325-1453), s.176.

${ }^{81}$ Türkiye, 30 Mayıs 1994; Selam, 2 Nisan 1994.

${ }^{82}$ Milliyet, 23 Aralık 1994.
} 
temel kaldıracı olmuştur. O zamandan günümüze kadar Ortodoks İttifakın sağladığı siyasi güç, başta Yunanistan olmak üzere Sırbistan, Bulgaristan, Romanya, Ermenistan, Rusya ve ABD tarafından değişik zaman periyotlarında ve değişik şekillerde kullanılmaya çalışılmış ve çalışılmaktadır. Zaman içerisinde oyuncuların etkinlikleri değişse de, ana fikir değişmemiştir. Ortodoks İttifakı'nın ana fikri, "Konstantinapolis"in başkent olduğu halde Bizans'ın ihya edilmesi, Anadolu topraklarından Türklerin ve Müslümanların sürülerek çıkarılması, haçın hilale karşı zaferinin sağlanmasıdır. ${ }^{83}$

Türkiye kendi iç dengeleri ve dinamikleri nedeniyle, daha önce Mussolini'nin yaptığı gibi İtalya topraklarında bağımsız bir dinî otorite devletinin kurulmasına sıcak bakamaz. Patrikhane'nin Ekümenikliği sadece Ortodoks Kiliselerini ilgilendiren bir mesele değil, aynı zamanda Türkiye'yi de bağlar. Bu durum en az Türkiye kadar Rusya Federasyonu'nu da yakından ilgilendirmektedir. "Kiliseler kendi aralarında halledip gelseler dahi, biz Lozan'ı önlerine koymak durumundayız." ${ }^{84}$ Rusya'nın endişesi, ABD'nin İstanbul Ortodoks Patrikhanesi'ni kontrol altına alarak yaklaşık 270 milyon Ortodoks dünyasına hâkim olacağı korkusudur. Ayrıca Patrik Türkiye Cumhuriyeti vatandaşıdır. Türk yasaları Patriğe "ekümenik" unvanını vermemiştir ve Patriğin siyasi etkinlikleri Türkiye Devleti’nin en temel ilkesi olan laikliğe tümüyle aykırıdır. Yargıtay'ın 2007 yılındaki kararında belirtildiği gibi, "ekümeniklik unvanının hukuksal bir temeli yoktur." 85 Patrik, mevcut yasaların kendine vermediği bir unvanı kullanıyorsa bu, devleti tanımamak anlamına gelir. İstanbul Ortodoks Patriği eğer yukarıda sıralanan ekümenik olma şartlarını yerine getiremiyorsa; siyasetten arınmış, huzur içinde yaşayan yerel bir Kilisenin Papazı, Türkiye'deki Rumların dinî lideri olma görevini onurla yürütmelidir.

\footnotetext{
${ }^{83}$ Erol Türkmenoğlu, “Ortodoks Birliği ve Türkiye”, Belgelerle Türk Tarih Dergisi, Dün Bugün Yarın, Say1: 102-103-104, Temmuz-Ağustos-Eylül 2005, İstanbul, s.126.

${ }^{84}$ Halil İnalcık, Milliyet, 3 Şubat 2008.

${ }^{85}$ Rıza Türmen, Milliyet, 5 Nisan 2010.
} 


\section{KAYNAKÇA}

Atatürk'ün Söylev ve Demeçleri, Cilt I-III, (1918 - 1937), Atatürk Kültür, Dil ve Tarih Yüksek Kurumu, Atatürk Araştırma Merkezi, Ankara, 1997.

Büyük Larousse Sözlük ve Ansiklopedisi, C.VII, İnterpress Basın ve Yayıncılık A.Ş., İstanbul,1986,

Türkiye Diyanet Vakfi İslâm Ansiklopedisi, XII, İstanbul, 1995, Bkz."Patrik” Mad.

Resmî Broşür: Ekumenical Patriarchate, Stephen and Catherin Pappas Boston, MA; USA (tarihsiz); Resmî Web Sitesi:www.patriarchate.org/28.05.2007.

Aktaş, Melih; “Patrikhane'de Rusya-ABD Savaşı”, Zaman, 21 Eylül 1995.

Alkan, Hakan; Fener Rum Patrikhanesi, Ankara, 1999.

Alkan, Hakan; Tarihsel Süreç İçerisinde Fener Rum Patrikhanesi ve Türkiye, Gazi Üniversitesi Sosyal Bilimler Enstitüsü, Ankara, 1996.

Altındal, Aytunç; "Casus Yuvası Patrikhane", Yeniçağ, 10 Kasım 2005.

Altındal, Aytunç; “Türkiye ve Ortodokslar”, Yeni Türkiye, Mart/Nisan 1995, Özel Sayı.

Atalay, Bülent; Fener Rum Ortodoks Patrikhanesi'nin Siyasi Faaliyetleri (19081923), Tarih ve Tabiat Vakfi Yayınları, İstanbul, 2001, s.259.

Aydın, Mehmet; "Batı ve Doğu Hristiyanlığına Tarihî bir Bakış", AÜIF Dergisi, Ankara, 1985, Sayı:27.

Benlisoy, Yorgo - Macar, Elçin; Fener Rum Patrikhanesi, Ankara, 1996.

Berkes, Niyazi; Patrikhane ve Ekümeniklik, Kaynak Yayınları, İstanbul, 2002.

Betterson, Henry; Documantes of the Christian Church, 2. Bask1, Oxford Univ. Press, 1963.

CNNTURK, 06 Aralık 2004, www.abgs.gov.tr/26.10.2007.

Çelik, Mehmet; Türkiye'nin Fener Patrikhanesi Meselesi, Akademi Kitabevi, İzmir, 1998.

Çelik, Mehmet; Fener Patrikhanesi'nin Ökümeniklik İddiasının Tarihî Seyri (3251453), Akademi Kitabevi, İzmir, 2000, s.153.

Çelik, Mehmet; Resmi Inciler: Kaynaklarl, Yazarları ve Hristiyan Literatüründeki Yerleri, Erzurum, 1981.

Çelik, Mehmet; Siyasal Sistem Açısından Bizans İmparatorluğunda Din-Devlet İlişkileri (Kuruluşundan

X. Yy.kadar), 2.Bask1, Elazı̆̆, 1995.

Çelik, Mehmet; Süryani Kilisesi Tarihi, Yaylacık Matbaası, İstanbul, 1987. 
Elekdağ, Şükrü; “Patrikhane'nin Statüsü”, Milliyet, 3 Aralık 1995.

Erzurumluoğlu, Kenan; "Patrikhane ve Pontus Dosyası: Kin Kapısı", www.ifsa.blogcu.com/15.11.2007.

İnce, Özdemir; Hürriyet, 12.12.2004.

Macar, Elçin; Cumhuriyet Döneminde İstanbul Rum Patrikhanesi, İstanbul, 2003.

Mısıroğlu, Kadir; Yunan Mezalimi, Türkün Siyah Kitabı, Sebil Yayınevi, İstanbul, 1966.

Ömeroğlu, Aydın; Türk Devleti ve Rum Patrikhanesi, Kim Kimin Dostu? Avcı Ofset, İstanbul, 1995.

Özekin, Muzaffer; Fener Rum Ortodoks Patrik'i Ekümenik mi, İrfan Yayımcılık, İstanbul, 2010.

Özfatura, Mustafa Necati; “İstanbul İkinci Vatikan Olma Yolunda”, Türkiye, 9 May1s 1994.

Sofuoğlu, Adnan; Fener Rum Patrikhanesi ve Siyasi Faaliyetleri, Turan Yayıncılık, İstanbul, 1996.

Şahin, Musa Süreyya; "Fener Rum Ortodoks Patrikhanesi”, Türkiye Diyanet Vakfi Íslam Ansiklopedisi, XII, İstanbul, 1995.

Şahin, Musa Süreyya; Türkiye'deki Patrikhaneler, İlke Yayıncılık, İstanbul, 2003.

Tüfekçioğlu, Turgay; Türkiye ve Şeytan Üçgeni, Hat Matbaası, Bursa, 2001.

Türk Dış Politikası, Ed. Baskın Oran, C.II, İletişim Yayınları, 1.Baskı Aralık 2001, İstanbul.

Türkmenoğlu, Erol; “Ortodoks Birliği ve Türkiye”, Belgelerle Türk Tarih Dergisi, Dün Bugün Yarın, Sayı: 102-103-104, Temmuz-Ağustos-Eylül 2005, İstanbul, s.126.

Ünaltay, Altay; “Ekümenik Patrik ve Tarihimizin Diğer 'Ekümenik' Kurumları”, Yeni Şafak, 12 Kasım 1995.

Yalçın, Emruhan; Atatürk Türkiye'sinde Ekümenik Ortodoks Patrikhanesi ve Bizans Projesi, Siyasal Kitabevi, Ankara, 2008.

Yalçın, Emruhan; Son Haçlı Kalesi: Heybeliada, Elips Kitap, Ankara, 2009.

Yıldırım, Münir; Yunanistan ve Ortodoks Kilisesi, Ankara, 2005.

Yıldırım, Uğur; Keşiş Güç, Otopsi Yayınları, İstanbul, 2005.

Cumhuriyet, 15 May1s 1950.

Cumhuriyet, 20 Temmuz 1997.

Günaydın, 13 Haziran 1994.

Hâkimiyeti Millîye, 20 Ocak 1923. 
Hürriyet, 9 Kasım 2009.

Hürriyet, 12.12.2004.

Milliyet, 3 Aralık 1995

Milliyet, 5 Kasım 2010.

Sabah, 24 Mayis 2005.

TGRT Haber, 25 Mayıs 2005.

Türkiye, 1 Aralık 1993.

Türkiye, 9 Mayıs 1994.

Vatan, 25.5.2005.

Yeni Şafak, 12 Kasım 1995.

Yunanistan (Türkiye'deki Yunan Büyükelçiliği tarafından yayımlanan bülten), Sayı:13, Haziran 2002.

Zaman, 20, 25 Eylül; 13, 23 Ekim 1995.

Nokta Dergisi, 4-10 Eylül 1994.

Aksiyon Dergisi, Sayı: 30, s.29.

Aksiyon Dergisi, 1-7 Temmuz 1995. 